\title{
Short term summer to autumn variability of dissolved lipid classes in the Ligurian sea (NW Mediterranean)
}

\author{
M. Goutx ${ }^{1}$, C. Guigue ${ }^{1}$, D. Aritio D. ${ }^{1}$, J. F. Ghiglione ${ }^{2,3}$, M. Pujo-Pay ${ }^{2,3}$, V. Raybaud ${ }^{4,5}$, M. Duflos ${ }^{1}$, and L. Prieur ${ }^{4,5}$ \\ ${ }^{1}$ CNRS-INSU UMR 6117, Laboratoire de Microbiologie, Géochimie et Ecologie Marines, Observatoire du Centre \\ d'Océanologie de Marseille, Campus de Luminy, 13288 Marseille Cedex 09, France \\ ${ }^{2}$ CNRS, UMR 7621, Laboratoire d'Océanographie Biologique de Banyuls, Avenue Fontaulé, BP44, \\ 66650 Banyuls sur mer, France \\ ${ }^{3}$ UPMC, Université Paris 06, UMR 7621, Laboratoire ARAGO, Avenue Fontaulé, BP 44, 66650 Banyuls sur mer, France \\ ${ }^{4}$ UPMC Université Paris 06, UMR 7093, Laboratoire d'Océanographie de Villefranche, BP 28, 06234 \\ Villefranche-sur-Mer cedex, France \\ ${ }^{5}$ CNRS, UMR 7093, Laboratoire d'Océanographie de Villefranche, BP 28, 06234 Villefranche-sur-Mer cedex, France
}

Received: 7 October 2008 - Published in Biogeosciences Discuss.: 6 January 2009

Revised: 19 May 2009 - Accepted: 2 July 2009 - Published: 21 July 2009

\begin{abstract}
Changes in concentration and composition of Iatroscan-measured dissolved lipids were examined at a daily to month scale, in relation to the hydrological and biological context at a central site of the Ligurian sea, NW Mediterranean during the PECHE-DYNAPROC 2 experiment (14 September to 17 October 2004). Lipid concentrations (excluding hydrocarbons) (TLd-HC) and TLd-HC to DOC ratios in the $0-1000 \mathrm{~m}$ water column, varied from 5.3 to $48.5 \mu \mathrm{gl}^{-1}$ and 0.01 to 0.09 , respectively. The highest TLd-HC concentration values were found in the 0 $50 \mathrm{~m}$ surface layer, coinciding with phytoplankton biomass. Significant correlations $(p<0.01, n=87)$ between glycolipids from chloroplast membranes, namely the monogalactosyldiacylglycerols, a major component of dissolved lipids ( $25.1 \pm 10.8 \%$ of TLd-HC, $n=166)$, and various phytoplankton pigments (chlorophyll cs-170, violaxanthin, diadinoxanthin, zeaxanthin, and lutein), suggested that picoeucaryote phytoplankton were a major source of dissolved lipids. Lipid metabolites (free fatty acids, alcohols, diacylglycerols and monoacylglycerols), an other important component of TLd-HC (37.6 $\pm 11.1 \%, n=166)$, showed a greater degree of degradation of lipids in this transitional period than previously observed earlier in the year. Zooplankton wax and steryl ester biomarkers (WSE) and triacylglycerols showed a distinct periodicity in the mesopelagic layer throughout the
\end{abstract}

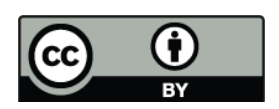

Correspondence to: $\mathrm{M}$. Goutx (madeleine.goutx@univmed.fr) period investigated. Concentrations of WSE (5.5-13.6 $\mu \mathrm{g} / \mathrm{l})$ increased in the $0-150 \mathrm{~m}$ surface layer, mid-way through the cruise (4-6 October), before the winter mixing. WSE were observed later and deeper in the mesopelagic layer (6-11 October), accompanied by rebounds in hydrocarbons (6-8 October) and phospholipid concentrations (12 October) in the 400-1000 m depth layer. Zooplankton migration and/or fecal pellet egestion, followed by DOM release from POM, were likely responsible for the appearance of these lipid signatures in the mesopelagic layer. Because we observed these signatures during low wind period only $(<15$ knots: 28 September-12 October), it may indicate that this organic matter transfer to depth was related to undisturbed trophic web in the water column above. The low salinity water lenses that appeared twice during the cruise in the 40-80 m surface layer had little effect on dissolved lipid concentrations. Lower concentrations in phosphoglycerides and hydrocarbons (HC) than in nearby sea water suggested different microbial assemblages and different level of HC contamination in this low salinity water.

\section{Introduction}

Marine dissolved organic matter (DOM) is an essential reservoir for the carbon cycle on Earth (Hansell and Carlson, 2002). In the ocean upper layer, photosynthesis yields organic material from inorganic carbon. Upon cell death, the

Published by Copernicus Publications on behalf of the European Geosciences Union. 
photosynthetically produced substances are released to the medium as dissolved compounds or particulate detritus that may be further transformed into DOM. Thus, primary production is one of the most important source of DOM eventhough DOM can be produced at each step of the food web. Proteins, carbohydrates and lipids are the major constituents of the fraction of DOM characterized at molecular level. Considerable attention has been given to this easily identifiable fraction because it is biologically labile, it contains bioavailable moities of biogeochemical interest like phosphorus and nitrogen and is a major substrate for marine bacteria. In addition, they may be used as biogeochemical markers to track the source, fate and transport of freshly biosynthesized DOM from the euphotic layer through the mesopelagic domain, under environmental forcings. Hence, despite the low percentage of these compounds (less than $11 \%$ ) in the DOM surface pool (Benner, 2002), understanding variations in concentrations, resistance to remineralization and transformation to more complex and refractory substances in the water column, is essential to better depict the process involved in the sequestration of photosyntheticallyproduced oganic carbon. Although DOM complex molecular assemblages would be better candidate for further characterisation (Mopper et al. 2007), the distribution of peptides, carbohydrates and lipids has not yet been clearly documented in the marine environment mainly due to limitations in methodologies.

Lipids represent from a few percent to $40 \%$ of the easily identifiable carbon fraction of DOM. They are membrane compounds, reserve products or metabolites from anabolism or catabolism in plankton cells (Parrish, 1988). Qualitative changes in their composition can be studied through the variability of selected lipid classes (Parrish, 1988), namely the cell membranes phospholipids and sterols from living organisms, the chloroplast membrane lipids (pigments and glycolipids) from autotrophic cells and phytodetritus, the reserve lipids from zooplankton (wax esters and triacylglycerols) and phytoplankton (triacylglycerols) and the degradation metabolites (free fatty acids, alcohols, di- and monoacylglycerols) of these source lipids, indicating the degradation status of the organic material (Goutx et al., 2000, 2003, 2005). They are released from living organisms through exudation, cell lysis or grazing, fueling the dissolved pool, and are further used by heterotrophic bacteria and/or exported to depth. The constitutive fatty acids of various lipids have been extensively used as biogeochemical markers of sources and diagenetic process of organic matter in suspended, sinking particles, and sediments (Saliot et al., 1991; Wakeham et al., 1995). Comparatively, dissolved lipid classes concentrations in the marine environment are poorly documented.

Dissolved lipids are operationally defined by filters that separate suspended particles from material including dissolved lipids, colloids, viruses and bacteria (Liu et al., 1998). Intact dissolved lipid classes have been studied in the extracellular medium of microalgae cultures to evaluate their pro- duction of food web substrates (Kattner et al., 1983; Parrish and Wangersky, 1987; Lombardi and Wangersky, 1991), to characterize extracellular substances that may be responsible for the toxicity of phytoplankton blooms (Parrish et al., 1994) and to identify tensio active substances in bacterial culture growing on hydrophobic substrates (Goutx et al., 1987, 1990). Recently, the need to find new biomarkers in the polar lipid fatty acids (glycolipids, phospholipids), and to understand the potential role of phospholipids in phosphorus cycling, has revived research on intact polar lipids and revealed the lack of data, on phospholipids in particular, and other intact dissolved lipids, in the marine environment (Suzumura, 2005). Comprehensive studies of the distribution and dynamics of dissolved lipid classes have mainly focussed on the transport of lipid DOM by rivers, estuaries and urban discharge at land/ocean interfaces (Parrish, 1987; Leveau et al., 1990; Jaffé et al., 1995; Derieux et al., 1998; Mannino and Harvey, 1999; Rütters et al., 2002). Only a few studies have reported on the distribution of dissolved lipid classes in the open sea (Parrish et al., 1988; Goutx et al., 1990; Gérin and Goutx, 1994; Liu et al., 1998).

Analytical limitations due to low lipid class concentrations in the open ocean are a major obstacle to the study of dissolved lipids in marine systems. The traditional methods of thin-layer or column chromatography, require a significant amount of material, which can be problematic in field studies. The TLC/FID technique involving an "Iatroscan" apparatus allows detection of low concentrations of lipids without prior splitting of the extract, and opens very interesting prospects by removing a major obstacle to the study of neutral and polar lipid classes in the marine environment. This analytical technique involves a qualitative separation of the lipid extract by thin-layer chromatography on Chromarods coupled to a quantification of separated compounds by flame ionization detection. Developments in the Iatroscan lipid analytical protocol have been proposed by Delmas et al. (1984), Gérin and Goutx (1993), Parrish et al. (1996) and Striby et al. (1999). As this methodology requires a small extract for lipid class separation compared to current methodologies, it requires less seawater and therefore seemed to be a priori a technique of choice enabling the exhaustive sampling required for describing short temporal or spatial scale variability of chemical organic species in marine ecosystems.

The project PECHE (Production and Export of Carbon: control by HEterotrophic organisms at short temporal scale) and its main operation, the oceanographic campaign DYNAPROC 2 (DYNAmics of rapid PROCesses), was designed by Valérie Andersen with the specific goal of assessing variability in the pelagic food web and its effect on biogeochemistry of the mesopelagic zone, targeting an oligotrophic system, the NW Mediterranean Sea at the end of the summer 2004. In the present study, using TLC/FID, we examined the short term changes in abundance and composition of neutral and polar dissolved lipid classes in the $0-1000 \mathrm{~m}$ water column. By processing a large set of $\sim 90$ samples at daily and 
monthly time scales at a fixed station in the open Ligurian sea, our overall objective was to better understand relationships between physical and biological forcings, and the short time variability of the organic chemical content in the water column, during the summer oligotrophy to autumn transitional period, in Northwestern Mediterranean.

\section{Material and methods}

\subsection{Study area and sample collection}

Samples were collected at a Time Series Station (TSS, 43 $25 \mathrm{~N}, 8 \mathrm{E}$; ca. $48 \mathrm{~km}$ offshore) in the Ligurian sea (NorthWestern Mediterranean) during the 2004 DYNAPROC 2 cruise (14 September to 17 October) on board the O/V Thalassa (Fig. 1). The dynamics of the biological system, in particular the phyto-, microzoo- and macrozooplankton biomasses and bacterioplankton, were studied in the 0 $1000 \mathrm{~m}$ water column during four cycles of 5 days each (Andersen et al., 2009), two cycles during Leg 1 (C1 and C2; 17-29 September) and two cycles during Leg 2 (C3 and C4; $3-16$ October). Sampling frequency was $3 \mathrm{~h}$ or $12 \mathrm{~h}$ depending on the parameter. For dissolved lipids, a minimum of two 0-1000 $\mathrm{m}$ CTD profiles were sampled at the beginning of each cycle (two profiles at $\mathrm{C} 1, \mathrm{C} 2$ and $\mathrm{C} 4$, and five profiles at $\mathrm{C} 3$ ) at $12 \mathrm{~h}$ interval (one around midnight and one around midday). Additional samples for lipid analysis were taken on two $0-150 \mathrm{~m}$ surface $\mathrm{CTD} /$ rosette profiles at $\mathrm{C} 1$, and at the sub-surface and chlorophyll maximum depths during the whole cruise, in order to obtain a continuous pattern of dissolved lipids in the surface layer (see the Supplement Table for the complete list of samples http://www.biogeosciences. net/6/1229/2009/bg-6-1229-2009-supplement.pdf).

\subsection{Dissolved lipid analysis}

Water was transferred from the Niskin bottles with a Teflon tube into 5 litre glass bottles previously washed with $2 \mathrm{M} \mathrm{HCl}$ and rinsed with MilliQ water. Four liters were gently filtered (pressure $<15 \mathrm{~mm} \mathrm{Hg}$ ) onto pre-combusted $\left(6 \mathrm{~h}\right.$ at $450^{\circ} \mathrm{C}$ ) $47 \mathrm{~mm}$ glass fiber filters $(\mathrm{GF} / \mathrm{F})$ using all-glass cylinders and filtration kits to separate suspended particles from dissolved organic material. All glassware was previously washed with RBS detergent, $2 \mathrm{M} \mathrm{HCl}$, then rinsed with MilliQ water and combusted for $6 \mathrm{~h}$ at $450^{\circ} \mathrm{C}$ or rinsed with acetone.

After adding the internal standard (I.S.) $(100 \mu \mathrm{l}$ of an hexadecanone solution at $0.2 \mathrm{mg} \mathrm{ml}^{-1}$ in dichloromethane), dissolved fractions (21) were liquid-liquid extracted on board using 4 times $100 \mathrm{ml}$ dichloromethane (Rathburn Chemical Ltd, HPLC grade) $(2$ times at $\mathrm{pH}<2)$. After phase separation, the organic phases were combined, the volume reduced with a rotary evaporator and stored at $-18^{\circ} \mathrm{C}$ under nitrogen atmosphere until analysis. The recovery of dissolved lipids was $70 \% \pm 13(n=167)$ based on the ketone internal standard. In order to examine the possibility of interference between

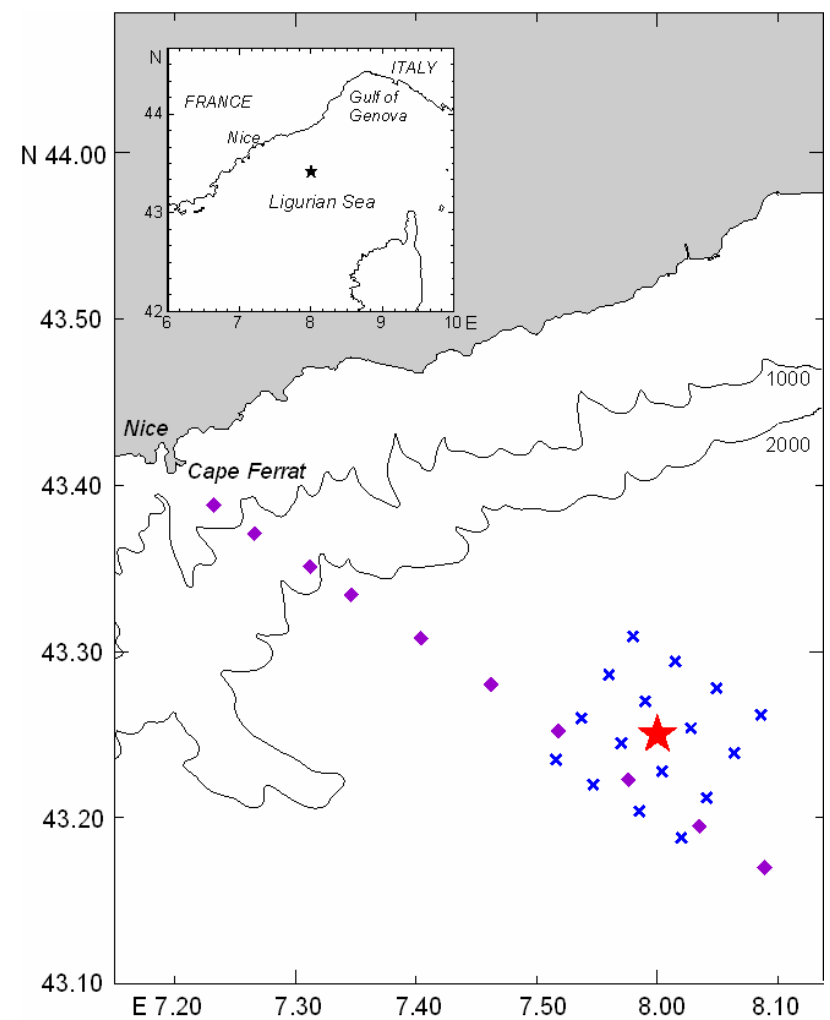

Fig. 1. Location of the time series station $(\star)$ sampled during the Dynaproc 2 cruise, and grid of stations that enabled to characterize the physics and hydrology of the area.

I.S. and natural ketones that might affect our extraction rates, a few additional samples were extracted without addition of the I.S. during extraction. In the particular case of these dissolved lipid extracts, in our analytical conditions, material at retention time similar to that of the I.S. remained below the detection level.

Dissolved lipid classes were separated on Chromarods by thin layer chromatography and quantified with flame ionisation detection (TLC/FID) in an Iatroscan apparatus model model MK-6 s (hydrogen flow, $160 \mathrm{ml} \mathrm{min}^{-1}$; air flow, $2000 \mathrm{~mL} \mathrm{~min}^{-1}$ ) coupled to a compatible PC equipped with an i-Chromstar 6.1 integration system (SCPA-Bremen, Germany). Samples (usually 4-6 $\mu 1$ of a $30 \mu 1$ solution of the lipid extract in dichloromethane) were spotted using a $2 \mu \mathrm{l}$ Hamilton syringe onto Chomarods-SIII previously calibrated with standard compounds (Sigma Chemical Ltd, GC grade). Analyses were run in triplicate.

The separation scheme involved five elution steps in solvents of increasing polarity: hexane+diethyl ether+formic acid, acetone, chloroform+methanol and chloroform+methanol+ammonium hydroxide according to a modified procedure of Goutx et al. (1990) described in Striby et al. (1999). The use of these elution systems separated neutral lipid classes (hydrocarbons, sterol esters co-eluting 
with wax esters, ketone as internal standard, triacylglycerols, free fatty acids, alcohols, sterols and diglycerides), chloroplast lipids (pigments, glycolipids) and monoglycerides, and non-nitrogen containing phospholipids (diphosphatidylglycerides co-eluting with phosphatidylglycerides) from nitrogen containing phospholipids (phosphatidylethanolamine and phosphatidylcholine). The relative standard deviation of replicate samples $(n=3)$ for Iatroscan TLC-FID analysis was below $12 \%$. Detection limit was $0.02 \mu \mathrm{gL}^{-1}$. Total dissolved lipids concentration (TLd-HC) was calculated by the summing of all lipid classes except hydrocarbons. As the biogenic origin of hydrocarbons could not be ascertained here, this lipid class is not included in TLd-HC that are thus referred to as biogenic lipids. Hydrocarbon dynamics were then treated separately. Molarity was calculated on the basis of the molecular weight of the reference standard for each lipid compound class.

\subsection{Dissolved organic carbon}

The samples were filtered through 2 precombusted $(24 \mathrm{~h}$, $450^{\circ}$ ) glass fiber filters (Whatman GF/F, $25 \mathrm{~mm}$ ), collected into precombusted glass tubes (closed with a screw cap and a Teflon liner), acidified with Orthophosphoric acid (H3PO4) and immediately analysed on board on a Shimadzu TOC$\mathrm{V}$ analyser. Dissolved organic carbon (DOC) was analyzed by high temperature catalytic oxidation (HTCO) (Cauwet, 1994, Cauwet 1999). Typical analytical precision is $\pm 0.1-$ 0.5 (SD) or $0.2-1 \%(\mathrm{CV})$. Deep Sargasso Sea reference water $(47 \mu \mathrm{M}, \pm 0.5 \mathrm{SE}$, http://www.rsmas.miami.edu/groups/ biogeochem/CRM.html) was injected every 10 to 12 samples to insure stable operating conditions.

\subsection{Ancillary parameters}

Meteorological (wind, rain), hydrological (temperature, salinity, density), biogeochemical (nutrients, oxygen, colored dissolved organic matter and pigments) and biological (bacteria, flagellates and ciliates, microphytoplankton, pico and nanophytoplankton, meso- and macrozooplankton) parameters were measured during this multidisciplinary cruise. CTD profiles were performed by using a Seabird SBE 25 probe measuring temperature, salinity, pressure, fluorescence, $\mathrm{O}_{2}$ and irradiance. Composition of phytoplankton was determined on the basis of a fine HPLC resolution of chlorophyll and carotenoid pigments, which for example included all chlorophylls, i.e. chl- $a$ and divinyl chl- $a$, chl- $b$ and divinyl chl- $b$, and chl- $c$ incuding $c 1, \mathrm{c} 2$ and cs-170 (Marty et al., 2008). Colored dissolved organic matter (CDOM) substances were extracted from $500 \mathrm{ml}$ sea water samples by adsorption on $\mathrm{C} 18$ microcolumns. CDOM was eluated from the microcolumn with methanol and quantified by lightabsorbance at $412 \mathrm{~nm}$. Data are available on the web site, in previously published papers (Marty et al., 2008) and in companion papers in the present BGS volume (Ghiglione et al.,
2008; Lasternas et al., 2008; Mevel et al., 2008; Mousseau et al., 2009; Raybaud et al., 2008, 2009)

\subsection{Statistics}

Correlation analyses between lipid classes and ancillary parameters were conducted using the statistics package of Microsoft Excel (Microsoft Office Professional Edition 2003). Pearson's correlation coefficients were determined for pairwise comparisons of total lipids, individual lipid classes and other environmental parameters (depth, salinity, temperature, oxygen, nutrients, DOC, particulate carbon, CDOM, Chl- $a$, phytoplankton pigments) with a significance level of $P<0.05$ assessed by Student's two-tailed $t$-test being considered significant. Values of $P<0.001$ were considered highly significant. The significance of mean comparison was assessed by ANOVA using the StatView 5 software.

\section{Results}

\subsection{General hydrological conditions}

The main hydro-biological characteristics during the cruise are presented in Fig. 2. Briefly, the DYNAPROC 2 cruise was conducted during the seasonal transitional period between summer and fall, a period marked by a decline in air temperature and the collapse of the summer water column stratification due to successive meteorologically forced mixing events. The cruise extended for two legs, 14-29 September (Leg1) and 2-17 October (Leg2). Concentrations of nutrients were low throughout the cruise (Marty et al., 2008). During Leg 1, two wind events from the NE occurred (17 and 25 September). At the end of the cruise, a succession of wind gusts (>20 Knots) from opposite directions: SW, NE and SW occurred over periods of $24 \mathrm{~h}, 60 \mathrm{~h}$ and longer until the end of the cruise from 10, 11 and 16 October, respectively. Temperature profiles showed a highly stratified water column from the beginning of the cruise to 10 October, being partially disrupted at the end of the cruise (Fig. 2a). The thermocline was strongly marked, with a mixed-layer temperature higher than $20^{\circ} \mathrm{C}\left(22^{\circ} \mathrm{C}\right.$ during weak wind periods $)$. This thermocline was located at approximately $25 \mathrm{~m}$ depth throughout the cruise. At the end of the cruise, the thermocline deepened to $40 \mathrm{~m}$ depth after the last two successive strong wind events accompanied by a decrease of air temperature and a cooling of the mixed water layer, which suggested the beginning of fall mixing.

Two intrusions of low salinity water masses (LSW) $(<38.3 \mathrm{psu})$ occurred below the thermocline (between 40 and $80 \mathrm{~m}$ ) (Fig. 2b). The first intrusion (LSW-1) lasted 5 days from julian day (JD) 265 (21-30 September) and the second intrusion (LSW-2) lasted for 4 days from JD283 (912 October). The coastal LSW did not affect the depths exceeding $300 \mathrm{~m}$. In 2004, the Levantine water was much more noticeable at the DYFAMED site than in previous years 

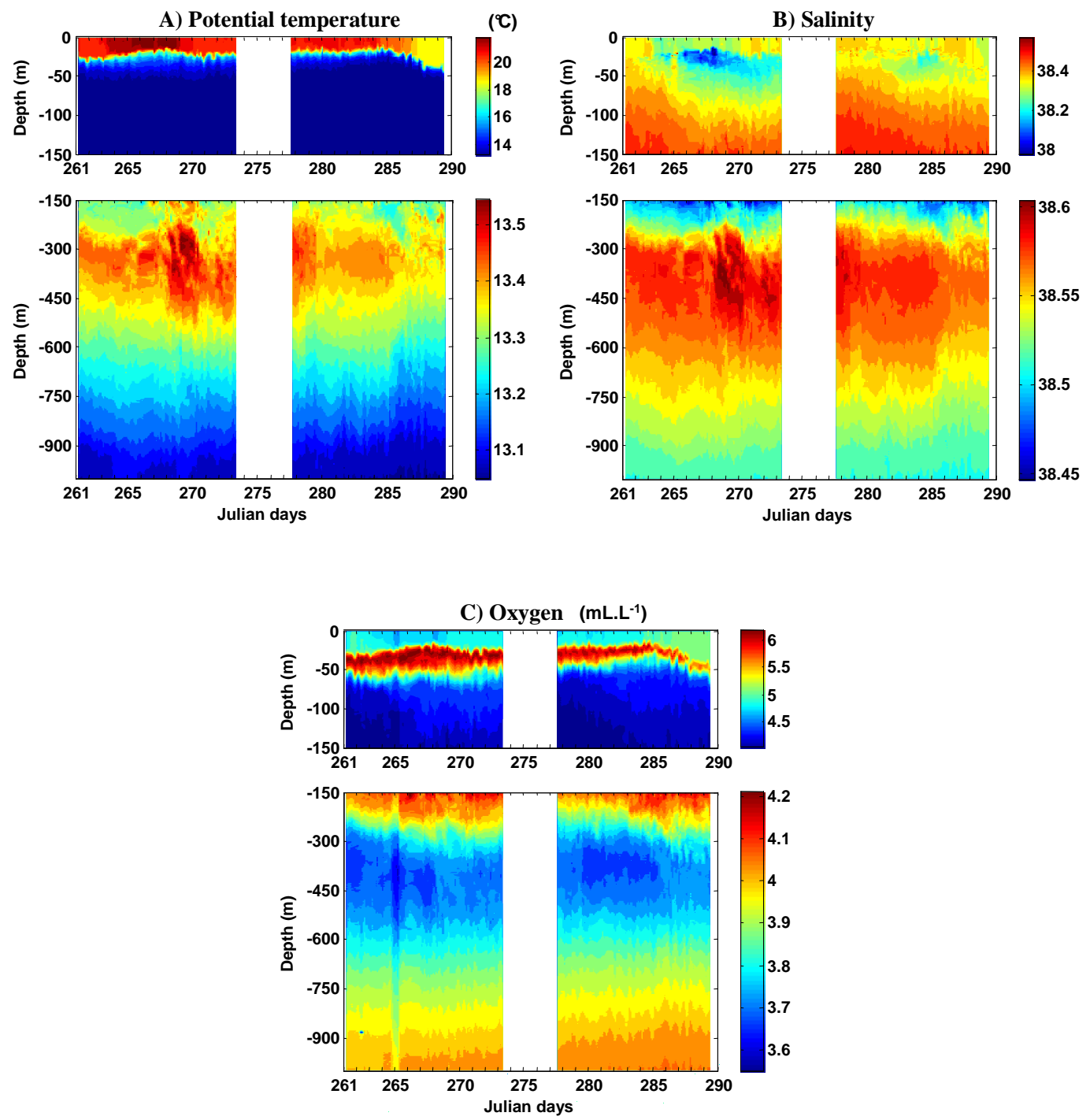

Fig. 2. Potential temperature $\left({ }^{\circ} \mathrm{C}\right)$, salinity (p.s.u.) and oxygen $\left(\mathrm{ml} \mathrm{L}^{-1}\right)$ at the Dynaproc 2 time series station $\left(43^{\circ} 25 \mathrm{~N}, 8^{\circ} \mathrm{E}\right)$ during the late summer to autumn transitional period.

(1970-1995) and remained at levels between 250 to $400 \mathrm{~m}$ depth in contrast to the frontal zone where it is found between 350 and over $600 \mathrm{~m}$ depth, taking salinity $>38.54$ and temperature theta $>13.4^{\circ} \mathrm{C}$ as a criterion for Levantine water at depth (below the temperature minimum of the surface layer). In 2004, the minimum of oxygen that characterized the Levantine water was $\mathrm{O}_{2}<3.8 \mathrm{ml} \mathrm{L}^{-1}$ (Fig. 2c). Variations in the thickness of the Levantine water during the DYNAPROC2 cruise remained within the bounds of small-scale spatial variability in the center of the Ligurian Sea. At the beginning of the cruise, two deep-chlorophyll maxima (DCM, 50-60 m and 90 m depth) were detected, displaying a phytoplankton biomass exceptionally high for this time of the year (integrated Chl- $a$ concentration of 35$40 \mathrm{mg} \mathrm{m}^{-2}$ ). After two days at the fixed station, only one
DCM (19 September, JD263), was observed at 40-50 m depth with a $0-150 \mathrm{~m}$ integrated value Chl- $a$ concentration of 20-25 $\mathrm{mg} \mathrm{m}^{-2}$ (Marty et al., 2008). The integrated primary production was $200 \mathrm{mg} \mathrm{C} \mathrm{m}^{-2} \mathrm{~d}^{-1}$ on average, varying from $400 \mathrm{mg} \mathrm{C} \mathrm{m}^{-2} \mathrm{~d}^{-1}$ at the beginning of the cruise (thus $50 \%$ higher than usually observed), down to $100 \mathrm{mg} \mathrm{C} \mathrm{m}^{-2} \mathrm{~d}^{-1}$ at the end of the cruise. The overall characteristics of the site show that the DYNAPROC2 cruise covered a period of the transitional regime between late summer and autumn (Andersen et al., 2009), but with hydrological and nutrient resources (N/P) similar to summer oligotrophic conditions (Marty et al., 2008). 


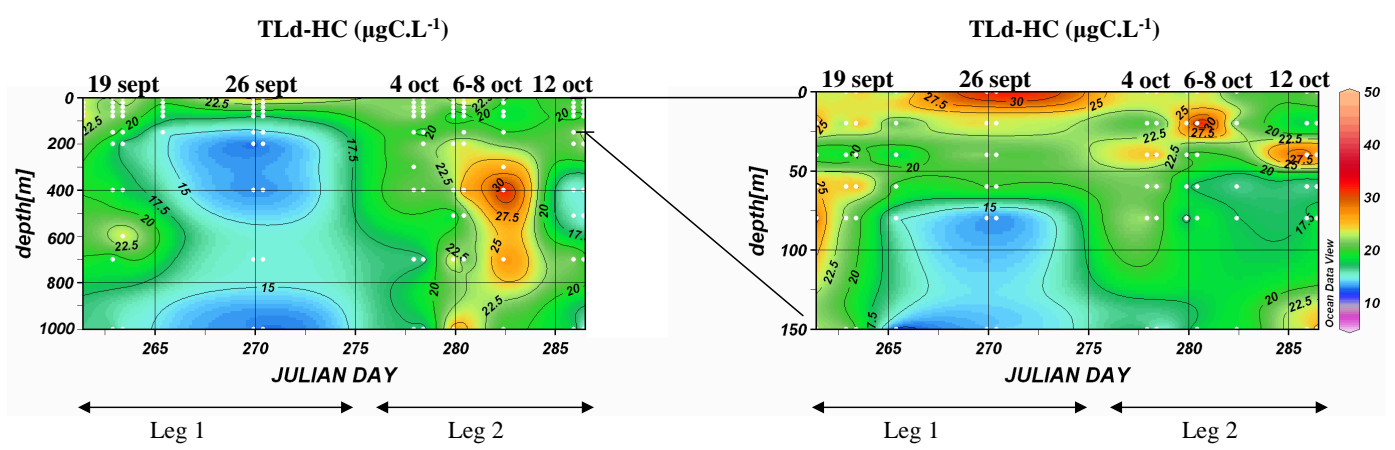

Fig. 3. Concentrations of total dissolved lipids (hydrocarbons not included) $\left(\mu \mathrm{gC} \mathrm{L}^{-1}\right)$ in the $1000 \mathrm{~m}$ (left) and in the surface $0-150 \mathrm{~m}$ (right) water column. Extrapolation ODV X and Y scale length 150.

TLd-HC ( $\left.\mu g C . L^{-1}\right)$
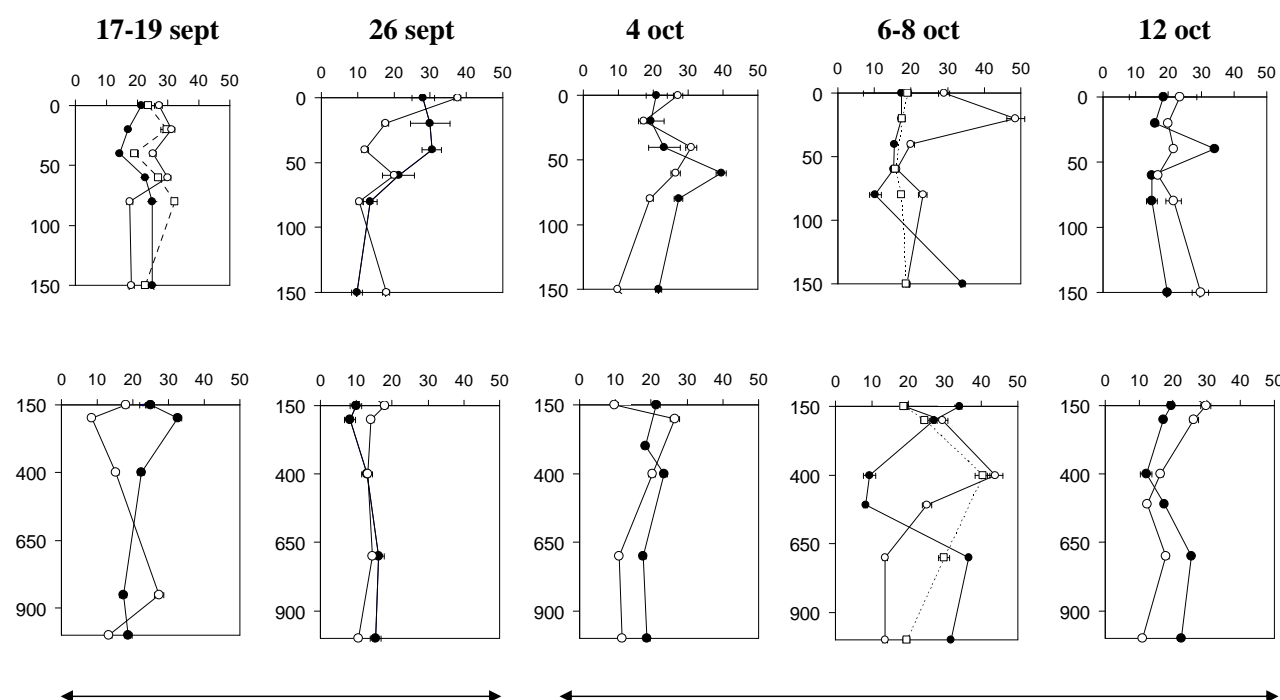

Leg 1
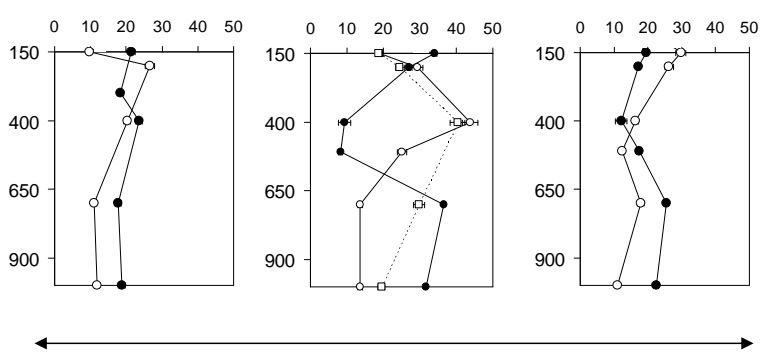

Leg 2

Fig. 4. Profiles of total dissolved lipids (hydrocarbons not included) $\left(\mu \mathrm{gC} \mathrm{L}^{-1}\right)$ in the $0-1000 \mathrm{~m}$ of the water column. Days (open symbols) and nights (filled symbols). Two additionnal day profiles (17 September and 8 October) are in dotted line.

\subsection{TLd-HC, TLd-HC to DOC ratios}

Lipid concentrations, hydrocarbons not included (TLd-HC), varied from 5.3 to $48.5 \mu \mathrm{gCl}^{-1}$ (0.4 to $4 \mu \mathrm{M}$ ) (See the supplemental data table http://www.biogeosciences.net/6/1229/ 2009/bg-6-1229-2009-supplement.pdf). The highest values were found in the upper $50 \mathrm{~m}$ of the water column (with exception of the data collected 19 September and 4 October) (Fig. 3). The concentration gradient with depth was more pronounced during Leg1, with TLd-HC values $\leq 18 \mu \mathrm{gC} \mathrm{L}^{-1}$ below $100 \mathrm{~m}$, than during Leg 2 when TLC-HC concentrations below the surface layer were up to $40 \mu \mathrm{gC} \mathrm{L}^{-1}$ (Fig. 3). An increase of concentrations in the mesopelagic layer occurred twice during the cruise, shortly at the beginning of Leg $1\left(27.4 \mu \mathrm{g} \mathrm{L}^{-1}, 19\right.$ September) at $600 \mathrm{~m}$ depth, and sev- eral times during Leg 2 (up to $43.9 \mu \mathrm{g} \mathrm{L}^{-1}$, between 6 and 12 October) in the $400-800 \mathrm{~m}$ layer. There was no clear day/night periodicity pattern in the TLd-HC profiles throughout the period investigated (Fig. 4): in the $0-150 \mathrm{~m}$ surface layer, peaks were observed at night in 3 over the 5 day/night profiles (26 September, 4 and 12 October). During leg 2 below $500 \mathrm{~m}$, TLd-HC concentrations were higher during the night than during the day (Fig. 4). DOC varied by a factor of 2 from surface to depth in the range 38.6-73.8 $\mu \mathrm{M}$. Concentrations $(70 \pm 2.5 \mu \mathrm{M})$ were maximal in the $0-10 \mathrm{~m}$ subsurface waters, then decreased following a moderate gradient down to $50.7 \pm 2.1 \mu \mathrm{M}$ in the $60-70 \mathrm{~m}$ water layer and were almost homogeneous down to a minimum value at $1000 \mathrm{~m}$ depth $(39.3 \pm 0.6 \mu \mathrm{M})$. There was no apparent difference between days and nights (Fig. 5). The contribution of TLd-HC 


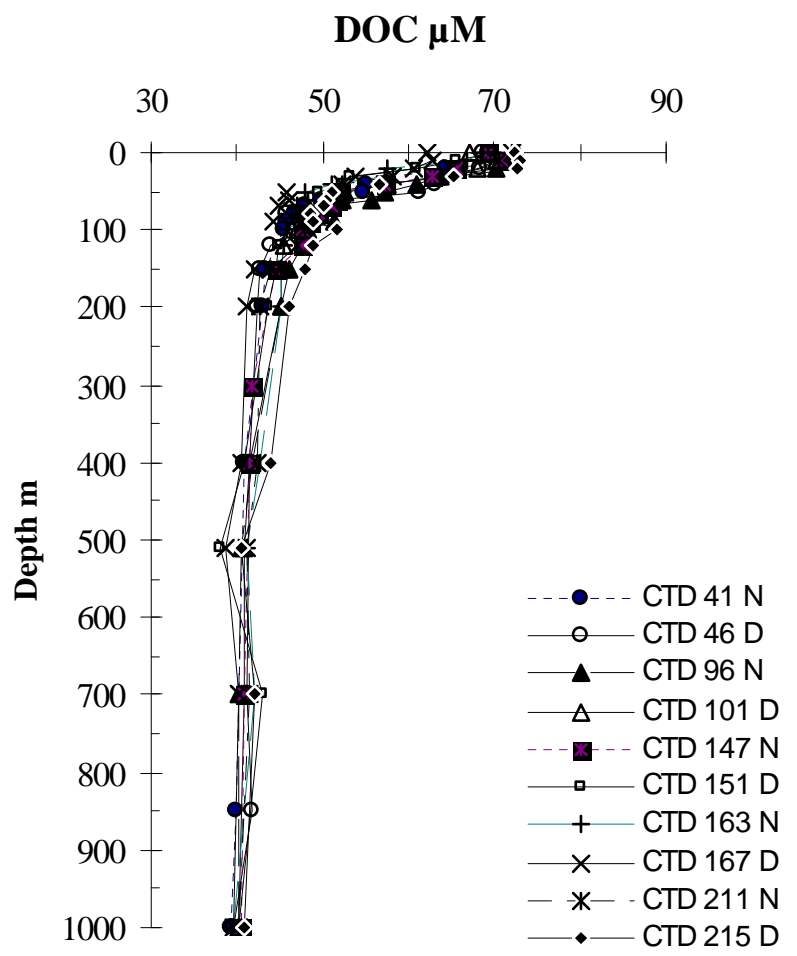

Fig. 5. Dissolved organic carbon concentrations $(\mu \mathrm{M})$. $\mathrm{N}=$ night, $\mathrm{D}=$ day.

to DOC varied in the range $0.9-9.1 \%$ (Fig. 6). The highest values $(\geq 7 \%)$ were observed within the $400-800 \mathrm{~m}$ depth layer, during the Leg 2 on 6 October during day and night, and 8 October during the day only, a pattern due to the increase of lipid concentrations while DOC concentrations remained quite stable. An increase in the percentage of TLd$\mathrm{HC}$ in DOC ( $>5 \%)$ was occasionally observed on a day profile, during Leg 1 (19 September at $700 \mathrm{~m}$, Julian day 263). In order to examine the lipid pattern in DOC at a seasonal scale, the average concentrations of DOC and total lipids were computed in the $0-150 \mathrm{~m}$ surface and the $150-1000 \mathrm{~m}$ mesopelagic layers during Leg 1 and 2 (Table 1). Overall, there was an increase in the contribution of dissolved lipids to DOC in the mesopelagic layer from an average $3.3 \pm 1.1 \%$ in September (Leg 1) to $4.3 \pm 1.8 \%$ in October (Leg2) (ANOVA, $p<0.05, n=31$ ), whereas the TLd-HC/DOC ratio in the 0 $150 \mathrm{~m}$ surface layer was similar $(2.9 \pm 1.1 \%$ and $3.1 \pm 1.1 \%$, during Leg 1 and Leg 2, respectively). There were no obvious differences in the daily variations of TLd-HC contribution to DOC (data not shown).

\subsection{Lipid classes}

Lipid class concentrations are presented in supplemental Table 1 http://www.biogeosciences.net/6/1229/2009/ bg-6-1229-2009-supplement.pdf. The relative contribution of phospholipids, chloroplast lipids (glycolipids and

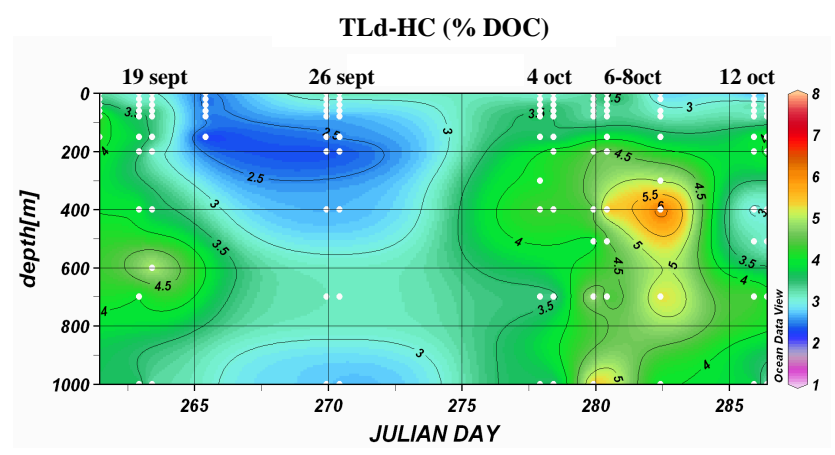

Fig. 6. Relative percentage of total dissolved lipids (hydrocarbons not included) in DOC. Extrapolation ODV X et Y scale length 150.

pigments), triacylglycerols (TG), wax and steryl esters (WSE) and metabolites (free fatty acids, alcohols, di- and monoacylglycerols) to the lipid pool showed a quite stable pattern during the sampling period (Fig. 7) with the exception of an increase of WSE and TG contribution to TLd-HC, from $5.1(n=1)$ to $15.1 \pm 11.7 \%(n=8)$ and from $4.1 \pm 1.8(n=12)$ to $4.0 \pm 3.0 \%(n=19)$ (data computed from supplemental Table $1 \mathrm{http}: / / \mathrm{www}$. biogeosciences.net/6/ 1229/2009/bg-6-1229-2009-supplement.pdf), respectively, beyond $200 \mathrm{~m}$ depth in the mesopelagic layer between Leg 1 and Leg 2. Table 2 provides the average concentration and percentage of lipid classes in TLd and TLd-HC during the whole cruise (all depths). Except for hydrocarbons, the glycolipids (monogalactosyl diacyglycerols) $(25.09 \%)$ were the major lipid class, followed by pigments (13.58\%), free aliphatic alcohols (12.34\%), the monoacylglycerols $(11.84 \%)$ and free fatty acids $(11.38 \%)$, and finally the phosholipids (PL). Thus the so-called chloroplast lipids, which include glycolipids and pigments, varied between $2.1 \mu \mathrm{gCL}^{-1}$ and $21.9 \mu \mathrm{gCL}^{-1}$ (see supplemental Table 1 http://www.biogeosciences.net/6/1229/2009/ bg-6-1229-2009-supplement.pdf) and dominated the lipid pool (38.7 $\pm 8.5 \%$ on average, $n=166)$ (Table 2), which suggested a phytoplankton source for DOM. The highest values were measured in the $0-80 \mathrm{~m}$ upper layer, at the beginning of Leg 2. High values (ca. $10-14 \mu \mathrm{gC} \mathrm{L}^{-1}$ were also found at depth in the 400-800 $\mathrm{m}$ layer (6 and 8 October) (see supplemental Table 1 http://www.biogeosciences.net/6/1229/2009/ bg-6-1229-2009-supplement.pdf). The other most important class of compounds were the lipid metabolites (FFA, ALC, MG and DG) $(37.6 \pm 11.1 \%$ on average, $n=166)$ (Table 2 and supplemental Table 1 http://www.biogeosciences. net/6/1229/2009/bg-6-1229-2009-supplement.pdf), indicating hydrolysis of lipid DOM. The average concentration of each lipid class per depth (data not shown) showed that free fatty acids had a maximal average concentration $\left(5.2 \pm 0.7 \mu \mathrm{gC} \mathrm{L}^{-1}\right)$ at $400 \mathrm{~m}$ depth, at the bottom of the Levantine water body. However, we did not sample properly the Levantine waters (only one sample was taken at $400 \mathrm{~m}$ 
Table 1. Average concentrations ( \pm standard deviation) of dissolved organic carbon (DOC) and dissolved total lipids (TLd-HC) (hydrocarbons not included) and percentage of TLd-HC in DOC, in the water column (0-1000 m), the surface (0-150 m) and the mesopelagic layers (150-1000 m) during the two legs of the cruise, September (Leg 1) and October (Leg 2).

\begin{tabular}{|c|c|c|c|c|c|}
\hline \multicolumn{3}{|c|}{ Dissolved Matter } & \multirow{2}{*}{$\begin{array}{c}\begin{array}{c}\text { DOC } \\
\mu \mathrm{M}\end{array} \\
53.6\end{array}$} & \multirow{2}{*}{$\begin{array}{c}\begin{array}{c}\text { TLd-HC } \\
\mu \mathrm{g} \mathrm{C} 1^{-1}\end{array} \\
18.4 \\
\pm 7.24(n=72)\end{array}$} & \multirow{2}{*}{$\begin{array}{c}\text { TLd-HC/DOC } \\
\% \\
3.0 \\
\pm 1.2(n=62)\end{array}$} \\
\hline Water column & $0-1000 \mathrm{~m}$ & September & & & \\
\hline & & October & $\begin{array}{c} \pm 11.1(n=62) \\
52.4 \\
\pm 11.3(n=91)\end{array}$ & $\begin{array}{c} \pm .24(n=12) \\
21.2 \\
\pm 8.42(n=95)\end{array}$ & $\begin{array}{c}3.5 \\
\pm 1.5(n=90)\end{array}$ \\
\hline \multirow[t]{2}{*}{ Surface } & $0-150 \mathrm{~m}$ & September & $\begin{array}{c}57.9 \\
\pm 9.75(n=46)\end{array}$ & $\begin{array}{c}19.6 \\
\pm 7.3(n=46)\end{array}$ & $\begin{array}{c}2.9 \\
\pm 1.1(n=46)\end{array}$ \\
\hline & & October & $\begin{array}{c}58.0 \\
\pm 10.1(n=63)\end{array}$ & $\begin{array}{c}21.0 \\
\pm 7.9(n=64)\end{array}$ & $\begin{array}{c}3.1 \\
\pm 1.1(n=63)\end{array}$ \\
\hline \multirow[t]{2}{*}{ Mesopelagic } & $150-1000 \mathrm{~m}$ & September & $\begin{array}{c}41.3 \\
\pm 1.9(n=16)\end{array}$ & $\begin{array}{c}16.3 \\
\pm 6.5(n=16)\end{array}$ & $\begin{array}{c}3.3 \\
\pm 1.3(n=16)\end{array}$ \\
\hline & & October & $\begin{array}{c}41.8 \\
\pm 1.8(n=32)\end{array}$ & $\begin{array}{c}21.5 \\
\pm 8.9(n=31)\end{array}$ & $\begin{array}{c}4.3 \\
\pm 1.8(n=31)\end{array}$ \\
\hline
\end{tabular}

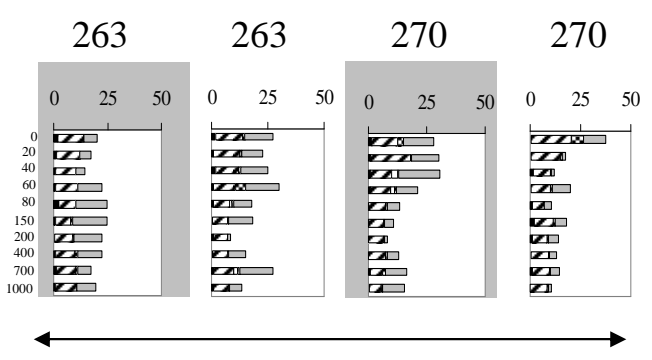

Leg 1 Phospholipids $\bigotimes$ Chloroplast lipids

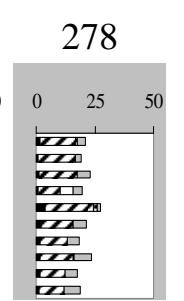
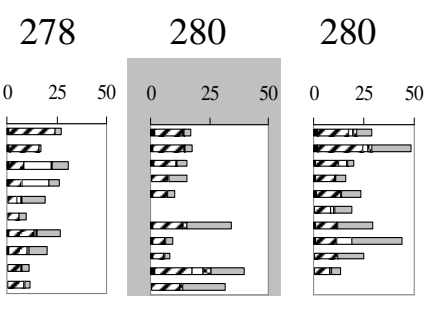

\section{2}

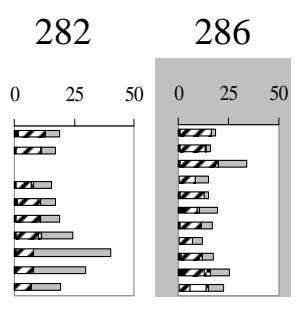

286

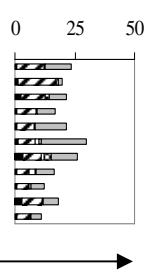

Leg 2

$\$$ Triacylglycerols

Fig. 7. Time series of TLd-HC $\left(\mu \mathrm{gL}^{-1}\right)$ and dissolved lipid class distribution (\% of TLd-HC) during night $(\square)$ and days $(\square)$ sampling. Julian days are above the graph.

depth in this water mass) and further characterisation of the lipid distribution in Levantine waters may not be performed straightforward. Other intact lipids (phospholipids, triacyglycerols, wax and steryl-esters) were present in lower proportions (on average $9.5 \pm 6.0 \%$ ). Phospholipids (PL) were the least abundant lipid class in the concentration range 0 $3.7 \mu \mathrm{gC} \mathrm{L}^{-1}$ (mean $1.0 \pm 0.6 \mu \mathrm{gCL}^{-1}, n=166$ ). A marked increase in PL concentrations was noticeable during leg2 at $150-200 \mathrm{~m}$ and $700 \mathrm{~m}$ depth (mean $3.1 \pm 0.3 \mu \mathrm{gC} \mathrm{L}^{-1}, n=4$ ) (Fig. 8, 12 October, upper panel). Finally, the hydrocarbon pool varied in the range $0.9-21.9 \mu \mathrm{gCL}^{-1}$ (on average $6.3 \pm 1.8 \mu \mathrm{gC} \mathrm{L}^{-1}$ ), which represented $24.7 \pm 3.2 \%$ of the TLd (Table 2). An increase of concentrations at $400-800 \mathrm{~m}$ depth occurred in 6 and 8 October (Fig. 8, lower panel).

The storage lipids, triacylglycerols (TG) and wax and steryl esters (WSE), varied in the range 0-6.0 and 0 $13.6 \mu \mathrm{gCL}^{-1}$, respectively. They were minor compounds not always present in the total lipids. Triacylglycerols are re- serve lipids in microalgae and zooplankton (Parrish, 1988). Wax and steryl esters cannot be easily separated by Iatroscan TLC/FID and there is no reports on wax versus steryl esters in dissolved lipids by using this technic. Steryl esters usually represent a small contribution to particulate WSE (usually less than 8\%) (Wakeham et al., 1980; Hudson et al., 2001). However, it is not always the case as shown by the high concentration measured in mesopelagic sediment trap in the Atlantic ocean (Wakeham et al., 1980). Ciliated protozoa also, are able to synthesize quantity of steryl esters (Kaneshiro, 1987). Whatever their relative proportions, wax and steryl esters are related to the presence of zooplankton (Sargent et al., 1976; Sargent et al., 1977; Sargent, 1978; Cavaletto et al., 1989; Kattner, 1989). In our study, the pattern of variation of TG and WSE over time and depth was well described by comparing the $0-150 \mathrm{~m}$ and $150-1000 \mathrm{~m}$ average concentrations (Fig. 9). During Leg 1, TG night average concentration values were always lower at surface $(0-150 \mathrm{~m})$ than in 
Table 2. Mean dissolved lipid class concentrations $(n=167)$ in the water column at the Dynaproc 2 central station during the summer to autumn transition period (14 September-17 October). Abbreviations used for lipid classes. Contribution of each lipid class to total dissolved lipids including HC (TLd) and contribution to total dissolved lipids (not including HC).

\begin{tabular}{lccccccc}
\hline Lipid class & Abbreviation & \multicolumn{2}{c}{ Concentration } & \multicolumn{3}{c}{ Contribution to } & \multicolumn{2}{c}{ Contribution to } \\
& & & \multicolumn{2}{c}{ TLd } & TLd-HC \\
& & $\mu \mathrm{L}^{-1}$ & $\pm \mathrm{SD}$ & $\%$ & $\pm \mathrm{SD}$ & $\%$ & $\pm \mathrm{SD}$ \\
\hline Hydrocarbons & $\mathrm{HC}$ & 6.33 & 1.81 & 24.69 & 3.25 & & \\
Wax and steryl esters & WE & 0.53 & 1.08 & 2.10 & 1.51 & 2.32 & 1.61 \\
Triglycerides & TG & 0.68 & 0.31 & 2.60 & 0.84 & 2.94 & 1.14 \\
Free fatty acids & FFA & 2.62 & 2.00 & 10.10 & 3.65 & 11.38 & 4.62 \\
Free aliphatic alcohols & ALC & 2.84 & 0.89 & 11.10 & 2.42 & 12.34 & 2.57 \\
1.3 Diglycerides & 1.3DG & 0.08 & 0.34 & 0.32 & 0.39 & 0.37 & 0.49 \\
Free sterols & ST & 0.01 & 0.08 & 0.04 & 0.10 & 0.05 & 0.11 \\
1.2 Diglycerides & 1.2DG & 0.01 & 0.06 & 0.04 & 0.06 & 0.05 & 0.08 \\
Chlorophyll pigments & PIG & 3.13 & 1.08 & 12.17 & 2.09 & 13.58 & 2.45 \\
Monoglycerides & MG & 2.73 & 1.36 & 10.64 & 2.85 & 11.84 & 3.37 \\
Monogalactosyldiglycerides & MGDG & 5.78 & 0.94 & 22.38 & 4.60 & 25.09 & 6.11 \\
Phosphoglycerides & PG & 0.86 & 0.23 & 3.31 & 0.80 & 3.71 & 1.00 \\
Phosphatidylethanolamines & PE & 0.11 & 0.05 & 0.41 & 0.11 & 0.46 & 0.12 \\
Phosphatidylcholines & PC & 0.01 & 0.02 & 0.04 & 0.03 & 0.04 & 0.03 \\
\hline
\end{tabular}
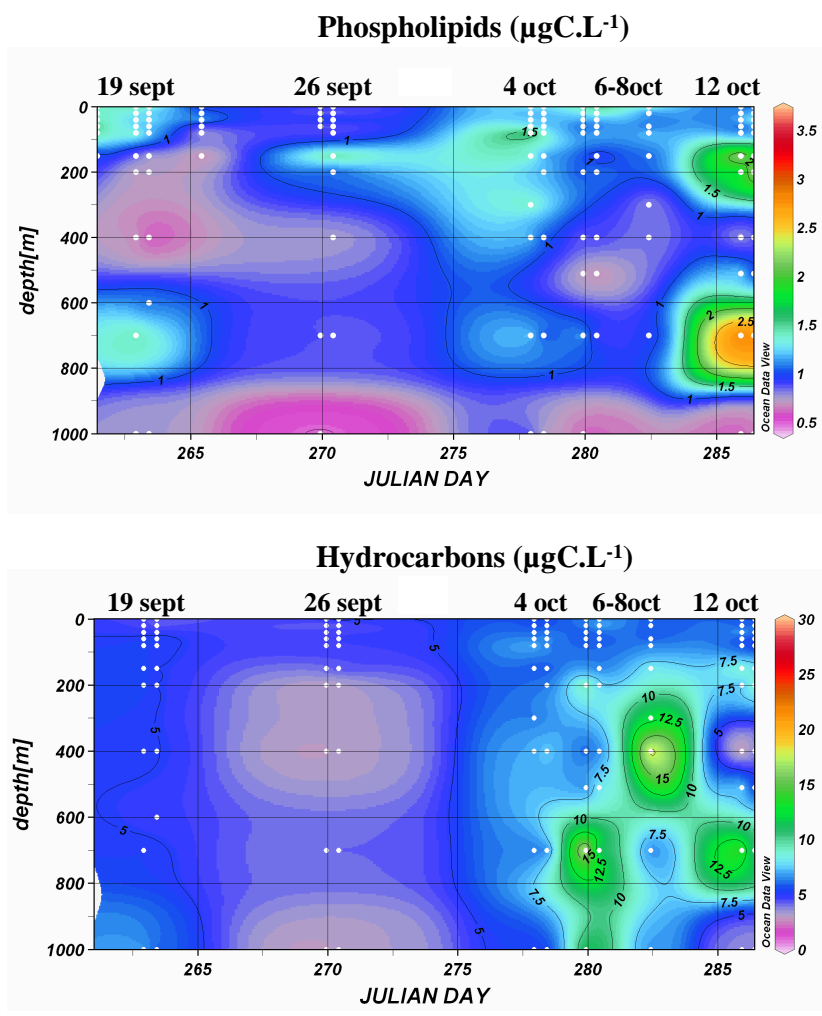

Fig. 8. Distribution of specific lipid markers $\left(\mu \mathrm{gC} \mathrm{L}{ }^{-1}\right)$. Dissolved phospholipids (upper panel), and hydrocarbons (lower panel). Extrapolation ODV X et Y scale length 150.

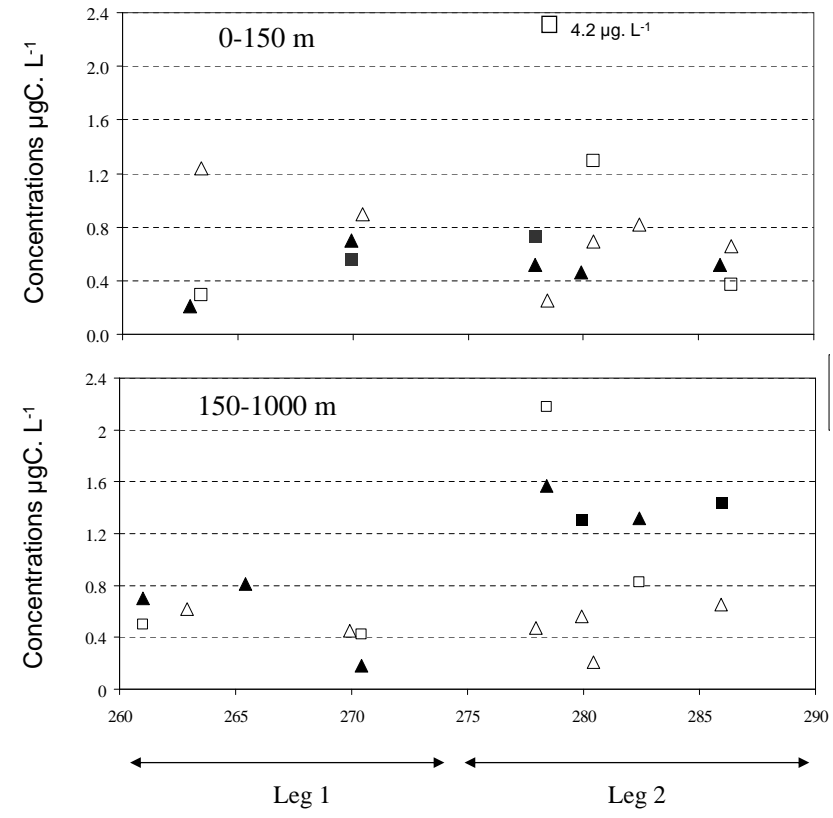

Fig. 9. Triacylglycerols (triangle) and wax esters (square) average concentrations $\left(\mu \mathrm{gC} \mathrm{L}^{-1}\right)$ based on integrated concentrations in the 0-150 m surface (upper panel) and mesopelagic 150-1000 $\mathrm{m}$ (lower panel) layers. Day (open symbols) and night (filled symbols). 


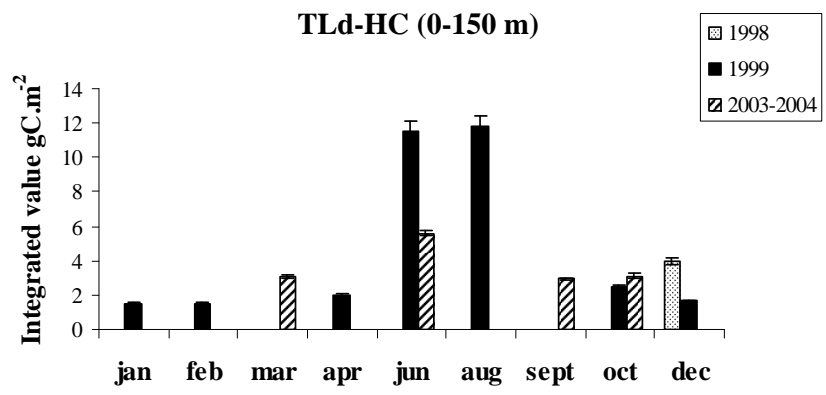

Fig. 10. Composite of total lipid concentrations measured in the framework of the Dyfamed time series observations (1998-1999) and in the framework of the PECHE project (March and June, 2003).

the mesopelagic layer, if we exclude night value observed at julian day 278. An opposite trend was observed for the TG day values, they were always higher at surface than in the mesopelagic layer. WSE occasionally appeared in the lipid pool during Leg 1 (Fig. 9). Like TG, WSE night values were lower at surface than in the mesopelagic layer but the day pattern was less obvious.

\subsection{Relationships between total lipids, individual lipid classes, and hydrological and biogeochemical pa- rameters}

Correlations between bulk organic compounds (DOC, particulate carbon, CDOM), TLd and TLd-HC, individual lipid classes, and environmental parameters (salinity, temperature, nutrients, Chl- $a$, phytoplankton pigments) were examined using Pearson's product-moment correlation coefficient. Correlations were computed on two matrices, a 0 $150 \mathrm{~m}$ matrix including all parameters cited above, and a 0 $1000 \mathrm{~m}$ matrix not including pigments because they were analyzed in the surface water column only. In the $0-1000 \mathrm{~m}$ water column, significant correlations were found between total dissolved lipids (both TLd and TLd-HC) and concentrations of hydrocarbons, triacylglycerols, chloroplast lipids and metabolites (free fatty acids and alcohols) $(p<0.01$, $n=167$ ) whereas the minor lipid classes (wax esters and phospholipids) were not correlated with total lipids (data not shown).

As chloroplast lipids (CL) were the major components of the lipid pool, the correlation between TLd-HC and CL suggests that phytoplankton were one major source of lipids in the $0-1000 \mathrm{~m}$ water column. In the $0-150 \mathrm{~m}$ surface water column, the monogalactosylglycerides (MGDG), which are constituents of CL in microalgae, were the only class of lipids that was significantly correlated with several individual pigments (chlorophyll cs-170 $(0.54, p<0.01)$, violaxanthin $(0.43, p<0.01)$, diadinoxanthin $(0.47, p<0.01)$, zeaxanthin $(0.52, p<0.01)$, and lutein $(0.49, p<0.01))$ which all together support the idea of a picoplanktonic sources of
MGDG in the dissolved lipid pool (Table 3). Such correlations between one component of the dissolved lipid fraction and pigments that are located inside the cells, suggest that a direct transfer of MGDG from the picoplankton intracellular lipid pool to dissolved lipids possibly occurred. MGDG was also correlated with DOC and particulate carbon (PC) (0.57 and $0.45, p<0.01$ ) (Table 3). This suggests that both PC and DOC contained a similar picoplankton material as TLd and/or that a PC to DOC transfer through picoplankton lysis and grazing is possible. In contrast, MGDG and coloured dissolved organic matter (CDOM) were not related to each other. CDOM, unlike MGDG, was not related to DOC, but was correlated with particulate carbon $(p<0.05, n=81)$, total fluorescence and almost all individual pigments including the five picoplankton pigments cited above (Table 3) indicating different CDOM sources from that of DOC.

\section{Discussion}

Our study provides the first high frequency time series measurements of total lipid concentrations and lipid class composition in DOM from the surface to the mesopelagic layer in the open Ligurian sea, which represents a reference for the late summer to autumn period in North Western Mediterranean. The amount of lipids that we measured in 2004 were in the lower range of values previously reported for marine coastal inlets and open sea areas $\left(11-580 \mu \mathrm{g} \mathrm{L}^{-1}\right)$ (Table 4).

\subsection{Seasonal variations of the total lipid pool}

Previous measurements of dissolved lipid concentrations (unpublished data; Ghiglione et al., 2007; Bourguet et al., 2009) at the Dyfamed TSS (Marty et al., 2002) during the 1998-1999 years, and during two additional PECHE shortcruises conducted in March and June 2003 (Andersen et al., 2009), enable to extend the temporal scale of the average lipid class concentrations measured in the $0-150 \mathrm{~m}$ euphotic layer during the Dynaproc2 cruise to an annual time series (Fig. 10): dissolved lipid concentrations were generally low in winter, maximal during summer oligotrophic period (June-August 1999 and June 2003) and returned to low values in autumn. Interestingly, this pattern suggests that lipid accumulations that occurred during summer oligotrophy (Van Wambeke et al., 2001; Bourguet et al., 2009) did not persist at the surface until the winter mixing. During late summer and autumn, lipids may be either remineralized, transformed through biotic and abiotic process into another type of material which is not captured by our analytical methodology, or exported to depth by other means than the mixing of water masses, namely through aggregation/dissolution and migration of zooplankton. 
Table 3. Results from pairwise moment correlation coefficients matrix. Significance of the correlation H0 : $R+0$; d.f. $=n-2=40$. Dark grey $=p<0.01$; light grey $=p<0.05 ;$ ns $=$ non significantly different from zero $->$ non correlated.

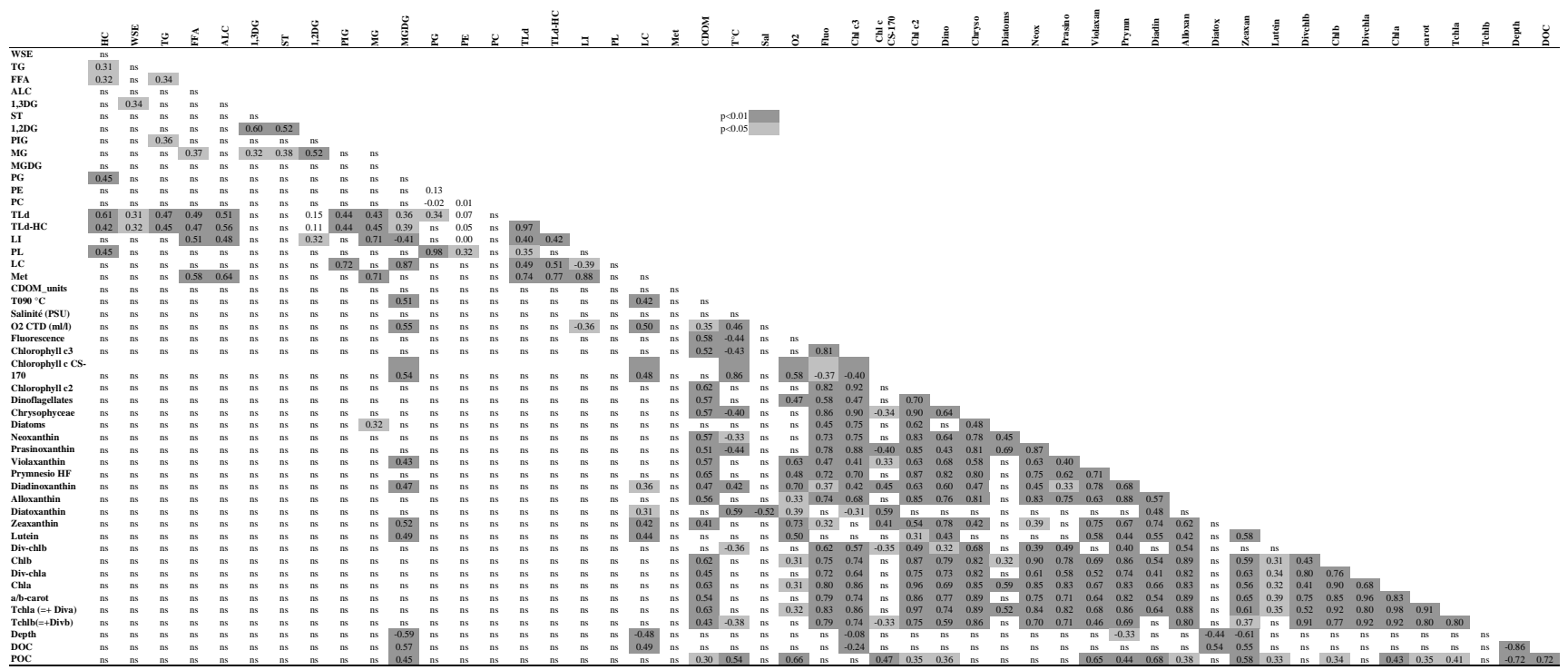

Table 4. Literature data of water column total dissolved lipid concentrations (TLd, $\mu \mathrm{g} \mathrm{L}^{-1}$ ) and total dissolved lipids not including hydrocarbons (TLd-HC, $\mu \mathrm{g} \mathrm{L}^{-1}$ ). All data were obtained by using TLC/FID except in Andersson et al. (1993) in which lipid extracts were weighted.

\begin{tabular}{|c|c|c|c|c|c|c|}
\hline References & Location & Latitude & Longitude & Depth & $\mathrm{TLd} \mu \mathrm{g} \mathrm{L}^{-1}$ & TL-HCLd $\mu \mathrm{g} \mathrm{L}-1$ \\
\hline Parrish, 1987 & Bedford basin, May-June 1982 & $44^{\circ} 41 \mathrm{~N}$ & $63^{\circ} 39 \mathrm{~W}$ & bottom of surface mixed layer & $75-498$ & $71-468$ \\
\hline Parrish et al., 1988 & Scotian slope, April 1982 & $44^{\circ} 39-44^{\circ} 41 \mathrm{~N}$ & $63^{\circ} 34 \mathrm{~W}-63^{\circ} 39 \mathrm{~W}$ & under the picnoclyne & $25-54$ & $13-48$ \\
\hline Parrish et al., 1992 & Nova Scotia inlet (Urban and Rural), August 1989 & $44^{\circ} 39 \mathrm{~N}$ & $63^{\circ} 34 \mathrm{~W}-63^{\circ} 39 \mathrm{~W}$ & euphotic layer & $96-156$ & $86-144$ \\
\hline Liu et al., 1998 & Conception Bay, time series 1991-1993 & $47^{\circ} 32 \mathrm{~N}$ & $53^{\circ} 06 \mathrm{~W}$ & euphotic layer $(10-28 \mathrm{~m})$ & $18-56$ & nd \\
\hline Striby and Goutx, 1997 & Gibraltar straight West, June 1997 & $35^{\circ} 55-36-06^{\circ} \mathrm{N}$ & $5^{\circ} 19 \mathrm{~W}$ & $10-230 \mathrm{~m}$ & nd & $17-135$ \\
\hline Striby and Goutx, 1997 & Gibraltar straight East, June 1997 & $35^{\circ} 53-36-04^{\circ} \mathrm{N}$ & $5^{\circ} 51 \mathrm{~W}$ & $10-300 \mathrm{~m}$ & nd & 94-229 \\
\hline Gérin and Goutx, 1994 & Almeria-Oran front, April 1991 & $35^{\circ} 43-36^{\circ} 51 \mathrm{~N}$ & $0^{\circ} 31-1^{\circ} 55 \mathrm{E}$ & $0-1600 \mathrm{~m}$ & $11-273$ & $9-113$ \\
\hline Striby, 2000 & Almeria Oran front, December 1997 & $35^{\circ} 43-36^{\circ} 51 \mathrm{~N}$ & $1^{\circ} 55-0^{\circ} 31 \mathrm{E}$ & $0-200 \mathrm{~m}$ & nd & $2-134$ \\
\hline Goutx et al., 1993 & NW Mediterranean, Avril 1989 & $43^{\circ} 35-43^{\circ} 31 \mathrm{~N}$ & $7^{\circ} 29-7^{\circ} 38 \mathrm{E}$ & $0-1000 \mathrm{~m}$ & $45-126$ & $33-112$ \\
\hline Van Wambeke, 2001 & NW Mediterranean, May 1995 & $43^{\circ} 25 \mathrm{~N}$ & $7^{\circ} 52 \mathrm{E}$ & $0-50 \mathrm{~m}$ & nd & $21-234$ \\
\hline Bourguet et al., 2008 & NW Mediterranean, March 2003 & $43^{\circ} 25^{\prime} \mathrm{N}$ & $7^{\circ} 52 \mathrm{E}$ & $3-500 \mathrm{~m}$ & nd & $12.4-40$ \\
\hline Bourguet et al., 2008 & NW Mediterranean, June 2003 & $43^{\circ} 25^{\prime} \mathrm{N}$ & $7^{\circ} 52 \mathrm{E}$ & $3-500 \mathrm{~m}$ & nd & $11.8-78$ \\
\hline Leveau et al., 1990 & Rhone plume, May 1988 & $43^{\circ} 19 \mathrm{~N}$ & $4^{\circ} 5 \mathrm{E}$ & plume, interface plume-sea water & $50-300$ & $35-152$ \\
\hline Derieux et al., 1998 & Gulf of Trieste, June 1995 & $45^{\circ} 39 \mathrm{~N}$ & $13^{\circ} 29 \mathrm{E}$ & euphotic layer & $49-88$ & $49-77$ \\
\hline Andersson et al., 1993 & Baltic sea, time series 1982 & $63^{\circ} 31 \mathrm{~N}$ & $19^{\circ} 50 \mathrm{E}$ & euphotic layer (0-14 m) & $25-270$ & nd \\
\hline Nichols and Espey, 1991 & Malabar sewage (Sydney) & $34^{\circ} \mathrm{N}$ & $151^{\circ} 5 \mathrm{E}$ & air-sea interface & $190-580$ & $190-580$ \\
\hline
\end{tabular}

\subsection{Source of dissolved lipids in the surface $0-150 \mathrm{~m}$ layer}

Lipids are an important component of DOM produced by phytoplankton during photosynthesis and a close relationship between Chl- $a$ and lipids was expected. However examinations of literature data from other systems (cf. Table 4) did not show any significant relationship between TLd-HC and Chl- $a$ despite a couple of high lipid concentrations acompanying the highest Chl- $a$ values in Bedford Basin (Parrish, 1987) or in the Rhone river plume (Leveau et al., 1990). Similarly, time series observations of dissolved lipid class concentrations during phytoplankton blooms have not revealed significant correlations between Chl- $a$ and TLd-HC (Morris et al., 1983; Parrish, 1987). In these studies, TLd-HC rather accumulated before and after the blooms. This suggests that either the dissolution of the detritic phytoplankton biomass into the dissolved pool need not be the major sources of dissolved lipid classes, or that only partially fractionated polar lipid classes would not be the best proxies for revealing such relationships. Indeed in the studies cited above (cf. Table 4), there was no separation of the acetone mobile polar lipid (AMPL) peak, the so-called chloroplast lipids, into its various components, i.e. monoglycerides (MG), pigments, and glycolipids (MGDG). These compounds have different origins and different susceptibility 
to bacterial attack. Degradation rates have been reported by several authors (Harvey et al., 1995, 1997; Goutx et al., 2003, 2007; Caradec et al., 2004; Moriceau et al., 2008). Goutx et al. (2003) and Moriceau et al. (2008) reported that as soon as mineral dissolution started, MGDG turned over more rapidly than the other AMPL lipids, i.e. the monoglycerides and pigments. Hence, due to differences in residence times, lipid classes resulting from diagenetic processes may have masked the origin of dissolved lipids.

In our study, the AMPL peak was fractionated into its various components (Striby et al., 1999), which may be the cause of the significant relation observed between a dissolved lipid class, the glycolipids (i.e. MGDG), and specific picoplankton pigments. This relation points out the picoeucaryotes as a major source of dissolved lipids during the period investigated.

One other reason for the lack of significant relationships between Chl- $a$ and dissolved lipids in our study and in previous works, may be that Chl- $a$ and AMPL that are enriched in large microphytoplankton cells, in particular diatoms, are preferentially exported to depth by aggregate formation through coagulation, and/or meso- and macrozooplankton grazing. Hence, large cells are less susceptible to breakdown through lysis and grazing in surface layers, having less potential for fueling the surface dissolved pool with intracellular Chl- $a$ and chloroplast lipids than small picoplankton cells do. The small picoplankton which is rich in xanthopigments, is most likely to enter the microbial loop, which would favour the export of its intracellular compounds to the dissolved pool through sloppy feeding.

A striking feature of the relationship between phytoplankton lipid biomarkers and organic matter descriptors was the significant correlations between particulate carbon (PC), DOC, glycolipids (MGDG) and picoplankton pigments on the one hand, and PC, CDOM, Chl- $a$, and most pigments on the other hand (cf. Results Sect. 3.3 and Table 3). This pattern suggested differences in sources and formation processes of bulk DOC and CDOM during the summer to autumn transitional period. The dynamics of DOC concentrations would mostly be controlled by release of matter from picoplankton that dominated the phytoplankton biomass (Marty et al., 2008) at this time of the year, probably through lysis, grazing and sloppy feeding. CDOM would rather be formed through intramolecular reactions of a larger range of organic biomolecules from the decaying pico- and microphytoplankton, under a combination of biotic and abiotic factors including light radiation (Yentsch and Reichert, 1961; Sieburth and Jensen, 1969).

Below $60 \mathrm{~m}$, the decrease of lipid concentrations suggested that stratification limited the transfer of phytoplankton lipids (and by extrapolation, of other phytoplankton material) from the productive layer to the mesopelagic layer. These conditions may result in a carbon limitation for the microbial population below this depth, which is consistent with observations made by Van Wambeke et al. (2009) during the Dynaproc2 cruise.

\subsection{Degradation statuts of the dissolved lipid pool}

An other important component of the dissolved lipid pool was the lipid metabolites (FFA, ALC, MG and DG). Release of metabolites occurs through the enzymatic cleavage of esters bounds of source glyceride lipids (Goutx et al., 2003). When the readily available molecules derived from phytoplankton start to be depleted, bacteria enzymatic activities cleave biopolymers into monomers (Hoppe, 1993). During the Dynaproc2 experiment, bacterial production was significantly correlated with the various organic matter descriptors (particulate carbon, DOC, MGDG and CDOM) (Mével et al., 2008; Ghiglione et al., 2008), which suggests that bacteria most probably were taking benefit from a wide range of biopolymers during this transitional period, because of varying growth limiting factors (Van Wambeke et al., 2009). Enzyme activity and bacterial production are not always tightly coupled, and accumulation of monomers (i.e. metabolites) is a function of this coupling/decoupling (Van Wambeke et al., 2001; Mullholand et al., 2007; Bourguet et al., 2009). Small lipid metabolites may be less reactive to bacteria than more complex and fresh biopolymers (Loh et al., 2004). In addition, lipid metabolite accumulation may reflect the presence of zooplankton digestive enzymes (Weeks et al. 1993). Finally, the accumulation of acyl lipid metabolites in the system may result from the maturation and shift of communities from autotrophic to heterotrophic as already reported in the Ligurian sea (Van Wambeke et al., 2001). This view is supported by the high contribution of metabolites to total dissolved lipids during late summer to autumn 2004 (on average $37.6 \pm 11.1 \%, n=166$ ), compared to spring and summer 2003 period $(23.9 \pm 16.9 \%(n=12)$ and $28.1 \pm 6.0 \%(n=16)$, respectively) (Bourguet et al. 2009). At the end of the stratified period, monoacylglycerols constituted the largest pool of metabolites, which may be related to the low reactivity of these compounds to bacterial lipase attack (Gurr and James, 1980).

\subsection{Inputs of dissolved lipids to depth}

Few studies have considered the dynamics of dissolved lipids beyond the euphotic layer. In our study, lipid concentrations exhibited a remarkable stability with a maximum of $40 \%$ variability in concentrations from surface to $1000 \mathrm{~m}$ depth throughout the period investigated. Such stability characterized several other biological and chemical parameters (Ghiglione et al., 2008; Lasternas et al., 2008; Marty et al., 2008; Mevel et al., 2008; Raybaud et al., 2008, 2009) that were studied during the Dynaproc cruise, probably due to the exceptional hydrological calm encountered during this late summer to autumn transitional period. 
In such hydrological conditions with limited physical and hydrological forcings, the impact of biology on dissolved lipid distribution likely prevailed. The larger variations of lipid concentrations in the $0-150 \mathrm{~m}$ surface layer compared to the 150-1000 m layer (cf. Table 1), were due to the high phytoplankton production and bacterial activity that characterized the euphotic layer during the sampling period, as reported by Marty et al. (2008) and Mevel et al. (2008), respectively, and that presumably released and consumed lipids at various rates. Below $150 \mathrm{~m}$ depth during leg 2, peaks of dissolved lipid and individual biomarker concentrations (cf. Figs. 2 and 8) reflected an input of lipids from surface to depth that was not related to the DOC export through the deepening of the mixed layer that we observed the last days of the cruise. It suggests that the mechanism responsible for lipid transport to the mesopelagic layer was different from that transporting the other DOC components. Because of the presence of zooplankton biomarkers in the $0-150 \mathrm{~m}$ layer in the early Leg 2 and later in the 400-700 m deep lipid peaks, one potential carrier may be the zooplankton through its daily migration (i.e., Raybaud et al., 2008), and production of fecal pellets, either in the productive layer or in the mesopelagic layer, followed by sedimentation and/or dissolution. Indeed, there were a clear day/night periodicity in the mesopelagic distributions of dissolved TG and WSE throughout the period investigated. The double signature of TG and WSE in sinking particles has already been related to fecal pellets of carnivorous euphausiids during Dynaproc 1 experiment (Goutx et al., 2000). Moreover, carnivorous zooplankton were identified as a major trophic element during the leg 2 (Mousseau et al., 2009).

The export of hydrophobic contaminants like petroleum hydrocarbons has been previously related to the vertical transport of lipid material in sedimenting particles (Andersson et al., 1993). As inferred during periods of increasing productivity, the nature of sinking particles may also impact the flux of these hydrocarbons. Bouloubassi et al. (2006) showed that the flux of fecal pellets was able to carry a significant fraction of petroleum hydrocarbons to depth. During the Dynaproc 2 cruise, the high proportion observed at $700 \mathrm{~m}$ during leg 2 may be related to egestion of fecal pellets from zooplankton, followed by disagregation/dissolution of the pellets within the mesopelagic layer, a scenario supported by the presence of zooplankton biomarkers at depth during Leg 2. At the surface, the origin of hydrocarbons may probably result from a background contamination of the lipid pool by petroleum hydrocarbons, as revealed by very high proportion $(24.7 \% \pm 3.2)$ in the dissolved lipids (Goutx, 1988).

Phospholipid signatures were noticeable later on during leg 2 (12 October) in the mesopelagic zone (Fig. 8). This change in phospholipid concentrations at $700 \mathrm{~m}$ depth between 6-8 October and 12 October amounted $1.5-2 \mu \mathrm{g} \mathrm{L}^{-1}$. Marine bacteria contain a range of $\sim 2-7 \%$ lipids in total carbon, free or bound to proteins and polysaccharides, with most lipids in the form of membrane phospholipids ( $88 \pm 5 \% \mathrm{TL})$
(Goutx et al., 1990; Goutx, unpublished). Because most bacteria may pass through the $0.7 \mu \mathrm{m}$ membrane, operationally defined for isolation of suspended particles from dissolved matter, bacteria may account for a substantial fraction of this deep "phospholipid" pool, as suggested by Wakeham et al. (2003). However, between 6-8 October and 12 October, the total bacterial biomass did not increase at this depth (Mevel et al., 2008). Increases were observed in free or nonparticle associated bacterial production $(\times 5)$ and abundance (above $910^{5}$ cells L $^{-1}$ ) (Mevel et al., 2008) and ecto-enzyme activities (F. Van Wambeke, personal communication, 2008). Using the conversion factor of Findlay et al. (1989) for naturally occurring mixed populations $\left(3.410^{9}\right.$ cells or $192 \mathrm{mg}$ of $\mathrm{C}$ per $100 \mathrm{nmol}$ of phospholipid), we evaluated the phospholipid increase as equivalent to $10^{7}-10^{8}$ cells $\mathrm{L}^{-1}$ bacteria, which is far above estimated bacterial concentrations, and does not support the idea that these phospholipids would represent only a bacterial biomass increase. Phospholipids may rather indicate the presence of cell remains either derived from the flux of sinking particles described above and/or from egestion of fecal pellets by migrator zooplankton in the mesopelagic layer. It is most probable that this input of fresh biopolymers at these depth occurred through particle dissolution and bacterial enzyme attack, stimulating the production of free living bacteria and promoting a mesopelagic microbial food web, which limited the bacterial abundance according to Tanaka and Rassoulzadegan (2004). We sampled sea water along 6 profiles for POC measurement in the $0-1000 \mathrm{~m}$ water column during the cruise. Among the four Leg 2 profiles, three profiles (11-13 October) clearly exhibited deep POC accumulation at $700 \mathrm{~m}$ depth $(\times 1.5$ to 2.5 folds the concentration in the $500 \mathrm{~m}$ depth above) (data not shown).

Finally, the above observations combine to show that an egestion of fecal pellets at the surface or in the mesopelagic layers by zooplankton and/or migrators, and their subsequent disintegration/dissolution through bacterial activity, sloopy feeding and grazing in the mesopelagic layer is a reasonable assumption that would explain the presence of lipid signatures in the deep water layers. This scenario is consistent with previous observations that slowly sinking particles derived from trophic chains based on small particles would rather dissolve within the mesopelagic layer at Dyfamed (Goutx et al., 2007). During Dynaproc 2, fecal pellets coming from the upper layers probably were emitted during the low wind period (25 September to 8 October), when high POC fluxes were recorded at $200 \mathrm{~m}$ depth (Marty et al., 2009), which is consistent with a slow sinking velocity for these agregates. These observations also support the conclusion of Bendtsen et al. (2002) about the Greenland Sea, that deep-sea labile DOC may only be explained by a DOC released from the sinking flux of POC. Dissolution of POM would led to formation of colloids known to preferentially shelter phospholipids (Liu et al., 1998). 

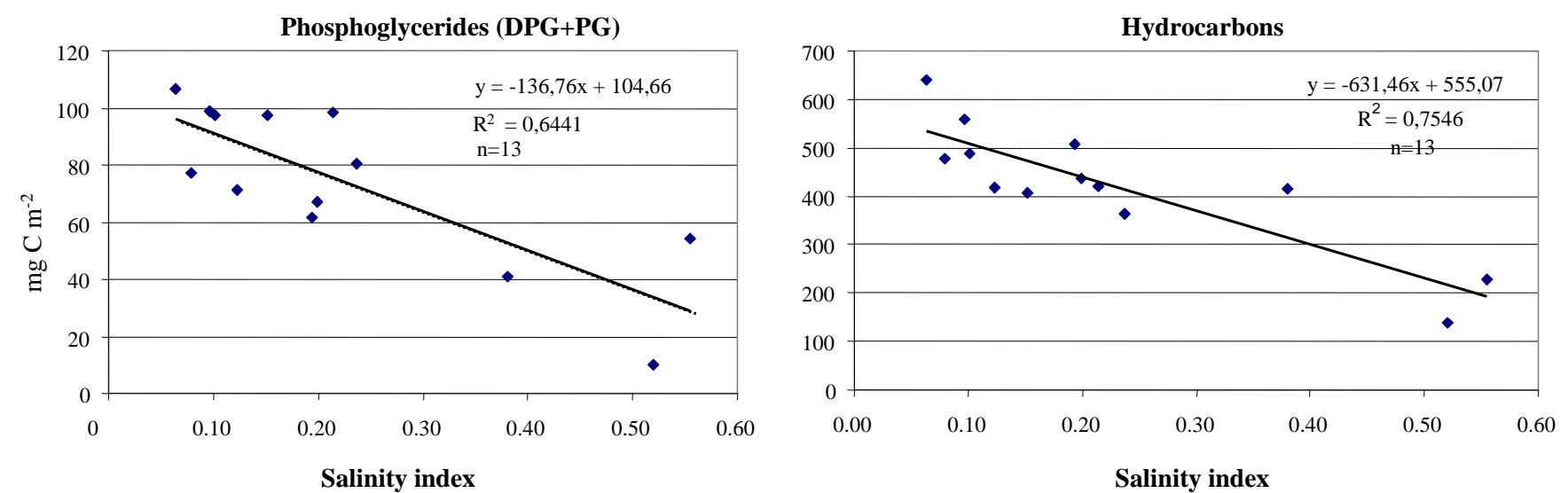

Fig. 11. Relationships between lipid biomarkers and salinity index. Lipid concentrations and Salinity index are integrated value between surface and $70 \mathrm{~m}$ depth.

\subsection{Relationship between lipid classes and low salinity index}

In order to compare chemical and biological parameters with low salinity events, an index in the range $0-1$ of the presence of lowered salinity or diluted waters in the upper water column was calculated, based on average salinity $S$ in the 40$70 \mathrm{~m}$ water layer, following the formula: Index $(\mathrm{sta})=(\mathrm{Smax}-$ $S($ sta $)) /(S \max -S \min ) ; S($ sta $)$ is the average salinity in the 40-70 m layer, Smin is that of the water taken as reference for low salinity water (coastal waters in our case), Smax is that of the salinity waters without anomaly.

Average lipid class concentrations were calculated similarly in the $40-80 \mathrm{~m}$ (we had no sample at $70 \mathrm{~m}$ depth). Regression between the low salinity index and lipid classes was significant (Fig. 11) showing that the low salinity water (LSW) had lower concentrations of phosphoglycerides and hydrocarbons than the nearby sea water (HSW). Phosphoglycerides are among the major phospholipids in cell membranes of procaryotes and eucaryotes. Recent studies have attempted to determine their relative distribution among bacteria, pico- and microphytoplankton (Van Mooy et al., 2006). The decrease of PG concentration in the LSW reflected the change in microbial assemblages in LSW compared to HSW, reported by Mevel et al. (2008) and Lasternas et al. (2008). Dissolution properties of hydrophobic compounds may account for the difference in hydrocarbons (HC) concentrations. It has been long established that organic compounds are generally less soluble in aqueous salt solutions, such as seawater, than in pure water (reduced by 1.36), a phenomenon termed "the salting-out effect" (Xie et al., 1997). Studies examining the influence of salinity on hydrocarbons and polycyclic aromatic hydrocarbon (PAH) solubility in seawater have yielded similar conclusions. For 12 aromatic hydrocarbons, Sutton and Calder (1975) and McAuliffe (1987) found that the mean reduction in solu- bility at $25^{\circ} \mathrm{C}$ in seawater was about $68 \%$, relative to fresh water. In our study, solubility was certainly not involved in the distribution of hydrocarbons (HC) since there was an opposite relationship between $\mathrm{HC}$ dissolution and salinity. Interactions between aromatic hydrocarbons and particles can be affected by salinity. Unfortunately particle size distribution was not investigated during the Dynaproc2 cruise. In our study, the higher concentrations of hydrocarbons in the high salinity water was surprising. Indeed, a higher contamination would be expected in waters coming from the coast, rather than from offshore sea water, due to ship concentration and/or resuspension of HC rich sediments in coastal zones. This finding suggests that chronic petroleum hydrocarbon discharge are important in NW Mediterranean and/or that other sources like atmospheric inputs may be significant. Finally, the time series of total dissolved hydrocarbon concentrations constitutes a unique data set for these compounds in offshore Mediterranean waters that may be of further use in environmental studies.

\section{Conclusions}

This study contributes to advances in DOM characterization by documenting the concentration and composition of dissolved lipids along the $0-1000 \mathrm{~m}$ surface and mesopelagic water layers in the central ligurian sea, NW Mediterranean. We conclude that different processes were involved in variability of dissolved lipids at short temporal and spatial scale throughout the water column. Changes in concentration and composition of dissolved lipid classes varied along the water column but significant variations also occurred during the summer to autumn transition. Values were high in the surface layer in relation to phytoplankton biomass where picoeucaryotes appeared to be the major source of dissolved lipids. In parallel, the variations of the system over time during the seasonal transition marked by nutrient limitations, corresponded 
to lipid degradation and metabolite accumulation that were higher than previously observed earlier in the year. During the transitional period, the stratification of the system was a factor limiting the distribution of fresh dissolved matter to depth. Under these conditions, the lipid biomarker pattern in the mesopelagic layer suggested strongly that the mesopelagic community was benefitting from DOM release from sinking POM due to zooplankton trophic behaviour, before the winter convection.

Acknowledgements. This study was part of the PECHE project; financial support was provided by the I.N.S.U.-C.N.R.S. through the PROOF program (JGOFS-France). We thank the chief scientist, $\mathrm{V}$. Andersen, for organising the DYNAPROC 2 cruise, and the crew of the R/V Thalassa for ship operations. We gratefull acknowledge all our colleagues who contributed to the sampling and measurements of physico-chemical parameters and in particular, R. Demesmay, J. C. Marty and A. 'Momzikoff. We thank J. Dolan for help and English corrections and anonymous referees for helpful comments on the manuscript. This paper is dedicated to our friend and colleague Valérie Andersen who prematurely passed away in March 2007 before she could participate in the valorisation of her oceanographic campaign.

Edited by: S. Pantoja

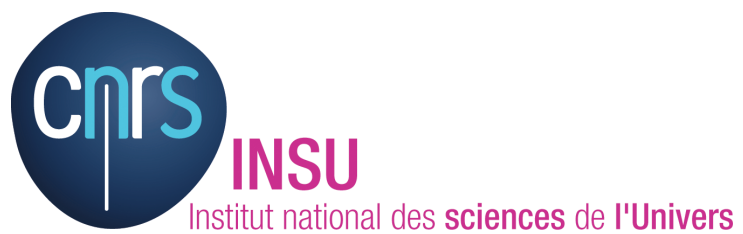

The publication of this article is financed by CNRS-INSU.

\section{References}

Andersen, V., Goutx, M., Prieur, L., and Dolan J. R.: Short-scale temporal variability of physical, biological and biogeochemical processes in the NW Mediterranean Sea: an introduction, Biogeosciences, 6, 453-461, 2009, http://www.biogeosciences.net/6/453/2009/.

Andersson A., Selstam E., and Hagstrom H.: Vertical transport of lipid in seawater, Mar. Ecol. Prog. Ser. 98, 149-155, 1993.

Bendtsen, J., Lundsgaard, C., Middelboe, M., and Archer, D.: Influence of bacterial uptake on deep-ocean dissolved organic carbon, Global Biogeochem. Cy., 16, 1127, doi:10.1029/2002GB001947, 2002.

Benner, R.: Chemical composition and reactivity , pp. 59-90, In: Biogeochemistry of Marine Dissolved Organic Matter, edited by: Hansell, D. and Carlson, C., Academic Press: Boston, 2002.

Bouloubassi, I., Méjanelle, L., Pete, R., Fillaux, J., Lorre, A., and Point, V.: PAH transport by sinking particles in the open Mediterranean Sea: A 1 year sediment trap study, Mar. Poll. Bull., 52, 560-571, 2006.

Bourguet, N., Goutx, M., Ghiglione, J. F., Pujo-Pay, M., Mével, G., Momzikoff, A., Mousseau, L., Guigue, C., Garcia, N., Raimbault, P., Pete, R., Oriol, L., and Lefèvre, D.: Lipid biomarkers and bacterial lipase activities as indicators of organic matter and bacterial dynamics in contrasted regimes at the Dyfamed site, NW Mediterranean, Deep-Sea Res. II, 56, 1454-1469, 2009.

Caradec, S., Grossi, V., Gilbert, F., Guigue, C., and Goutx, M.: Influence of redox conditions (oxic, redox oscillation, anoxic) on the degradation of microalgal triacylglycerols and fatty acids in marine sediments, Org. Geochem., 35, 277-287, 2004.

Cauwet, G.: HTCO method for dissolved organic carbon analysis in seawater: influence of catalyst on blank estimation, Mar. Chem., 47, 55-64, 1994.

Cauwet, G.: Determination of dissolved organic carbon (DOC) and nitrogen (DON) by high temperature combustion, in: Methods of seawater analysis, edited by: Grashoff, K., Kremling, K., and Ehrhard, M., 3 rd edition, Wiley-VCH, Weinheim, 407-420, 1999.

Cavaletto, J. F., Vanderploeg, H. A., and Gardner, W. S.: Wax esters in two species of freshwater zooplankton, Limnol. Oceanogr., 34, 785-789, 1989.

Delmas, R. P., Parrish, C. C., and Ackman, R. G.: Determination of lipid class concentrations in seawater by thin-layer chromatography with flame ionization detection, Anal. Chem., 56, 12721277, 1984.

Derieux, S., Fillaux, J., and Saliot, A.: Lipid class and fatty acid distributions in particulate and dissolved fractions in the North Adriatic Sea, Org. Geochem., 29, 1609-1621, 1998.

Derieux, S.: Biogéochimie de la matière organique dans deux environnements marins côtiers, le Golfe de Trieste et le Delta du Danube - Etude des classes de lipides et des acides gras, Thèse de Doctorat, Université Pierre et Marie Curie, Paris VI, Paris, 167 pp., 1998.

Findlay, R. H., King, G. M., and Watling, L.: Efficacity of phospholipid analysis in determining microbial biomass in sediments, Appl. Environ. Microbiol., 55, 2888-2893, 1989.

Gérin, C. and Goutx, M.: Iatroscan -measured particulate and dissolved lipids in the Almeria-Oran frontal system (Almofront-1, Leg B, May 1991), J. Mar. Sys., 5, 343-360, 1994.

Gérin, C. and Goutx, M.: Separation and quantitation of phospholipids in marine bacteria by Iatroscan TLC/FID analysis, J. Plan. Chromatogr., 6, 307-312, 1993.

Ghiglione, J. F., Palacios, C., Marty, J. C., Mével, G., Labrune, C., Conan, P., Pujo-Pay, M., Garcia, N., and Goutx, M.: Role of environmental factors for the vertical distribution $(0-1000 \mathrm{~m})$ of marine bacterial communities in the NW Mediterranean Sea, Biogeosciences, 5, 1751-1764, 2008, http://www.biogeosciences.net/5/1751/2008/.

Ghiglione, J. F., Mevel, G., Pujo-Pay, M., Mousseau, L., Lebaron, P., and Goutx, M.: Diel and seasonal variations in abundance, activity, and community structure of particle-attached and freeliving bacteria in NW Mediterranean Sea, Microb. Ecol., 54, 217-231, 2007.

Goutx, M., Acquaviva, M., and Bertrand, J. C.: Cellular and extracellular carbohydrates and lipids from marine bacteria during growth on soluble substrates and hydrocarbons, Mar. Ecol. Progr. Ser., 61, 291-296, 1990.

Goutx, M., Gérin, C., and Bertrand, J. C.: An application of Iatroscan thin-layer chromatography with flame ionization detection - Lipids classes of microorganisms as biomarkers in the marine environment, Org. Geochem., 16, 1231-1237, 1990.

Goutx, M., Guigue, C., and Striby, L.: Triacylglycerol biodegradation experiment in marine environmental conditions : definition 
of a new lipolysis index, Org. Geochem., 34, 1465-1473, 2003. Goutx, M., Guigue, C., Leblond, N., Desnues, A., Dufour, A., Aritio, D., and Guieu, C.: Particle flux in the North-East Atlantic Ocean during the POMME experiment (2001): Results from Mass, Carbon, Nitrogen and lipid biomarkers from the drifting sediment traps, J. Geophys. Res., 110, C07S20, doi:10.1029/2004JC002749, 2005.

Goutx, M., Momzikoff, A., Striby, L., Andersen, V., Marty, J. C., and Vescovali, I.: High frequency fluxes of labile compounds in the Central Ligurian sea, Northwestern Mediterranean, Deep Sea Res. Pt I, 47, 533-556, 2000.

Goutx, M., Moriceau, B., Lee, C., Liu, Z., Guigue, C., Duflos, M., Tedetti, M., Sempere, R., Wakeham, G. S., and Xue, J.: Composition and degradation of marine particles with different settling velocities, Limnol. Oceanogr., 52, 1645-1664, 2007.

Goutx, M., Mutafschiev, S., and Bertrand, J. C.: Lipids and exopolysaccharids production during the n-alkanes growth of a marine bacteria isolated from sea - surface, Mar. Ecol. Progr. Ser., 40, 259-267, 1987.

Goutx, M.: Particulate lipid survey in the Bedford basin (Nova Scotia) using thin-layer chromatography with flame ionization detection. Comparison of hydrocarbon data with gas-chromatography analyses, Mar. Envir. Res., 26, 83-95, 1988.

Gurr, M. I. and James, A. R.: Lipid Biochemistry: An Introduction, Chapman and Hall eds., London, 1980.

Hansell, D. A. and Carlson, C. A.: Biogeochemistry of Marine Dissolved Organic matter, Academic Press: Boston, 2002.

Harvey, H. R. and Macko, S. A.: Kinetics of phytoplankton decay during simulated sedimentation: changes in lipids under oxic and anoxic conditions, Org. Geochem., 27, 129-140, 1997.

Harvey, H. R., Tuttle, J. H., and Macko, S. A.: Kinetics of phytoplankton decay during simulated sedimentation: changes in biochemical composition and microbial activity under oxic and anoxic conditions, Geochim. Cosmochim. Acta, 59, 3367-3377, 1995.

Hudson, E. D., Helleur, R. J., and Parrish, C. C.: Thin layer chromatography-pyrolysis-gas chromatography-mass spectrometry: A multidimensional approach to marine lipid class and molecular species analysis, J. Chromatogr. Sci., 39, 146-152, 2001.

Hoppe, H.-G.: Significance of exoenzymatic activities in the ecology of brackish water: measurments by means of metthylumbelliferyl-substrates, Mar. Ecol. Prog. Ser., 11, 299308, 1983.

Jaffé, R., Wolf, G. A., Cabrera, A. C., and Carvajal-Chitty, H. I.: The biogeochemistry of lipids in rivers of the Orinoco Basin, Geochim. Cosmochim. Acta, 59, 4507-4522, 1995.

Kaneshiro, E. S.: Lipids of Paramecium, Journal of Lipid Resarch, 28, 1241-1258, 1987.

Kattner, G.: Lipid composition of Calanus finmarchicus from the north sea and the arctic. A comparative study, Comparative Biochemistry and Physiology, 94, 185-188, 1989.

Kattner, G., Gercken, G., and Hammer, K. D.: Development of lipids during a spring plankton bloom in the northern North Sea II. Dissolved lipids and fatty acids, Mar. Chem., 14, 163-173, 1983.

Lasternas, S., Tunin-Ley, A., Ibañez, F., Andersen, V., Pizay, M.D., and Lemée, R.: Dynamics of microphytoplankton abundance and diversity in NW Mediterranean Sea during late summer con- dition (DYNAPROC 2 cruise; September-October 2004), Biogeosciences Discuss., 5, 5163-5202, 2008,

http://www.biogeosciences-discuss.net/5/5163/2008/.

Leveau, M., Lochet, F., Goutx, M., and Blanc, F.: Effects of a plume front on the distribution of inorganic and organic matter off the Rhône river, in: Fluxes between trophic levels and through the water sediment interface, edited by: Bonin, D. J. and Golterman, H. L., Hydrobiol., 207, 87-93, 1990.

Liu, Q., Parrish, C. C., and Helleur, R.: Lipid class and carbohydrate concentrations in marine colloids, Mar. Chem., 10, 367387, 1998.

Loh, A. N., Bauer, J. E., and Druffel, E. R. M.: Variable ageing and storage of dissolved organic components in the open ocean, Nature, 430, 877-881, 2004.

Lombardi, A. T. and Wangersky, P. J.: Influence of phosphorus and silicon on lipid class production by the marine diatom Chaetoceros gracilis grown in turbidostat cage cultures, Mar. Ecol. Prog. Ser., 77, 39-47, 1991.

Mannino, A. and Harvey, R.: Lipid composition in particulate and dissolved organic matter in the Deleware Estuary: Sources and diagenetic patterns, Geochim. Cosmochim. Acta., 63, 22192235, 1999.

Marty, J.-C. and Chiavérini, J.: Seasonal and interannual variations in phytoplankton production at DYFAMED time-series station, northwestern Mediterranean Sea, Deep-Sea Res. Pt. II, 49, 2017 2030, 2002.

Marty, J. C., Garcia, N., and Raimbault, P.: Phytoplankton dynamics and primary production under late summer conditions (DYNAPROC II cruise September/October. 2004, NW Mediterranean Sea), Deep-Sea Res. Pt. I, 55, 1131-1149, 2008.

McAuliffe, C. D.: Organism exposure to volatile/soluble hydrocarbons from crude oil spills - a field and laboratory comparison, Oil Spill Conf., American Petroleum Industry, Washington, DC, 357-363, 1987.

Mével G., Vernet, M., Goutx, M., and Ghiglione, J. F.: Seasonal to hour variation scales in abundance and production of total and particle-attached bacteria in the open NW Mediterranean Sea (0 1000 m), Biogeosciences, 5, 1899-1932, 2008, http://www.biogeosciences.net/5/1899/2008/.

Meyers, P. A. and Ishiwatari, R.: Lacustrine organic geochemistry: an overview of indicators of organic matter sources and diagenesisin lake sediments, Org. Geochem., 20, 867-900, 1993.

Mopper, K., Stubbins, A., Ritchie, J. D., Biak, H. M. and Hatcher, P. G.: Advanced instrumental approaches for characterization of marine dissolved organic matter: Extraction techniques, mass spectrometry and nuclear magnetic resonance spectroscopy, Chem. Rev., 107, 419-442, 2007.

Moriceau, B., Goutx, M., Lee, C., Guigue, C., Armstrong, R., Tamburini, C., Charrière, B., Duflos, M., and Ragueneau, O.: The role of Si-C interactions during degradation of the diatom Skeletonema costatum, Deep-Sea Res. II, http://www.msrc.sunysb. edu/MedFlux/pages/pubspres.html\#Pub, 2008.

Morris, R. J., McCartney M. J., and Robinson, G. A.: Studies of a spring phytoplankton bloom in an enclosed experimental ecosystem; I: Biochemical changes in relation to the nutrient chemistry of water, J. Exp. Mar. Biol. Ecol., 70, 249-262, 1983.

Mousseau, L., Lefevre, D., Narcy, F., Nival, P., and Andersen, V.: A one-month study of the zooplankton community at a fixed station in the Ligurian Sea: the potential impact of the species compo- 
sition on the mineralization of organic matter, Biogeosciences Discuss., 6, 995-1019, 2009,

http://www.biogeosciences-discuss.net/6/995/2009/.

Mulholland, M. R., Gobler, C. J., and Lee, C.: Peptide hydrolysis, amino acid oxidation, and nitrogen uptake in communities seasonally dominated by Aureococcus anophagefferens, Limnol. Oceanogr., 47, 1094-1108, 2002.

Nichols, P. D. and Espey, Q. I.: Characterization of organic matter at the air-sea interface in subsurface water and in bottom sediments near the Malabar sewage outfall in Sydney's coastal region, J. Mar. Freshwater Res., 42, 327-348, 1991.

Parrish, C. C.: Separation of aquatic lipid classes by Chromarod thin-layer chromatography with measurement by Iatroscan flame ionization detection, Can. J. Fish. Aquat. Sc., 44, 722-731, 1987.

Parrish, C. C.: Dissolved and particulate marine lipid classes: a review, Mar. Chem., 23, 17-40, 1988.

Parrish, C. C. and Wangersky, P. J.: Particulate and dissolved lipid classes in cultures of Phaeodactylum tricornutum grown in cage culture turbidostats with a range of nitrogen supply rates, Mar. Ecol. Prog. Ser., 35, 119-128, 1987.

Parrish, C.C., Wangersky, P. J., Delmas, R. P., and Ackman, R. G.: Iatroscan-measured profiles of dissolved and particulate marine lipid classes over the Scotian Slope and in Bedford basin, Mar. Chem., 23, 1-15, 1988.

Parrish, C. C., Bodennec, G., and Gentien, P.: Time course of intracellular and extracellular lipid classes in batch cultures of the toxic dinoflagellate, Gymnodinium nagasakiense, Mar. Chem. 48, 71-82, 1994.

Parrish, C. C., McKenzie, C. H., MacDonald, B. A., and Hatfield, E. A.: Seasonal studies of seston lipids in relation to microplankton species composition and scallop growth in South Broad Cove, Newfoundland, Mar. Ecol. Prog. Ser., 129, 151-164, 1995.

Parrish, C. C., Bodennec, G., and Gentien P.: Determination of glycoglycerolipids by Chromarod thin-layer chromatography with Iastroscan flame ionization detection, J. Chromatogr. A, 741, 91-97, 1996.

Raybaud, V., Tunin-Ley, A., Ritchie, M. E., and Dolan, J. R.: Similar patterns of community organizationcharacterize distnict groups of different tropic levels in the plankton of the NW Mediterranean Sea in autumn 2004, Biogeosciences, 6, 431-438, 2009

Raybaud, V., Nival, P., Mousseau, L., Gubanova, A., Altukhov, D., Khvorov, S., Ibaòez, F., and Andersen, V.: Short term changes in zooplankton community during summer-autumn transitional in the open NW Mediterranean Sea: species composition, abundance and diversity, Biogeosciences, 5, 1765-1782, 2008.

Rütters, H., Sass, H., Cypionka, H., and Rullkötter, J.: Phospholipid analysis as a tool to study complex microbial communities in marine sediments, J. Microbiol. Meth., 48, 149-160, 2002.

Saliot, A., Laureillard, J., Scribe, P., and Sicre P.: Evolutionary trends in the lipid biomarker approach for investigating the biogeochemistry of organic matter in the marine environment, Mar. Chem., 36, 223-248, 1991.

Sargent, J. R.: Marine wax esters, Science Progress Oxford, 65, 437-458, 1978

Sargent, J. R., Gatten, R. R., and MacIntosh, R.: Wax esters in the marine environment: their occurrence, formation, transformation and ultimate fate, Mar. Chem., 5, 573-584, 1977.

Sieburth, J. M. N. and Jensen, A.: Studies on algal substances in the sea. II. The formation of Gelbstoff (humic material) by exudates of phaeophyta, J. Exp. Mar. Biol. Ecol., 3, 275-289, 1969.

Smith, R. E. H., Gosselin, M., Kattner, G., Legendre, L., and Pesant, S.: Biosynthesis of macromolecular and lipid classes by phytoplankton in the Northeast Water Polynya, Mar. Ecol. Prog. Ser., 147, 231-242, 1997.

Striby, L.: Biogéochimie de la matière organique dans deux écosystèmes marins. Cas d'une structure physique unidimensionnelle verticale (mer Ligure) et d'une structure physique frontale (front Almeria-Oran). Variations spatio-temporelles de la fraction lipidique à petite échelle. $\mathrm{PhD}$ from "Université de la Méditerranée, Aix-Marseille 2", Dpt Sciences de l'Environnement Marin, OSU-COM, pp. 292, 2000.

Striby, L. and Goutx, M.: Lipids in the Strait of Gibraltar in June 1997, in: Fluxes and outflow from the Mediterranean, MAST3CANIGO, 1st Scientific Meeting, Madrid, Spain, November 1997, Abstract in: Minutes of the MAST3-CANIGO meeting, 1997.

Striby, L., Lafont, R., and Goutx, M.: Improvment in the Iatroscan thin-layer chromatography-flame ionisation detection analysis of marine lipids, Separation and quantitation of mono- and diacylglycerols in standards and natural samples, J. Chromatogr. A., 849, 371-380, 1999.

Sutton C. and Calder, J. A.: Solubility of alkylbenzenes in distilled water and seawater at $25^{c}$ irc C, J. Chem. Engin. Data, 20, 320322, 1975.

Suzumura, M.: Phospholipids in marine environments: a review, Talanta, 66, 422-434, 2005.

Tanaka, T. and Rassoulzadegan, F.: Vertical and seasonal variations of bacterial abundance and production in the mesopelagic layer of the NW Mediterranean Sea: bottom-up and top-down controls, DSR I, 51, 531-544, 2004.

Van Mooy, B. A. S., Rocap, G., Fredricks, H. F., Evans, C. T., and Devol, A. H.: Sulfolipids dramatically decrease phosphorus demand by picocyanobacteria in oligotrophic marine environments, PNAS, 6(103), 8607-8612, 2006.

Van Wambeke, F., Goutx, M., Striby, L., Sempéré, L., and Vidussi, F.: Bacterial dynamics during the transitional from spring bloom to oligotrophy in the Northwestern Mediterranean sea. Relationships with particulate detritus, dissolved organic matter and the structure of the microbial food web, Mar. Ecol. Prog. Ser., 212, 89-105, 2001

Van Wambeke, F., Ghiglione, J.-F., Nedoma, J., Mével, G. and Raimbault, P.: Bottom up effects on bacterioplankton growth and composition during summer-autumn transition in the open NW Mediterranean Sea, Biogeosciences, 6, 705-720, 2009.

Wakeham, S. G.: Lipid biomarkers for heterotrophic alteration of suspended particulate organic matter in oxygenated and anoxic water columns of the ocean, Deep Sea Res., Part I, 42, 1749 $1771,1995$.

Wakeham, S. G., Farrington, J. W., Gagosian, R. B., Lee, C., De Baar, H. J. W., Nigrelli, G. E., Tripp, B. W., Smith, S. O., and Frew, N. M.: Organic matter fluxes from sediment traps in the equatorial atlantic ocean, Nature, 286, 798-800, 1980.

Wakeham, S. G., Pease, T. K., and Benner, R.: Hydroxy fatty acids in marine dissolved organic matter as indicators of bacterial membrane material, Org. Geochem., 34, 857-868, 2003.

Weeks, A., Conte, M. H., Harris, R. P., Bedo, A., Bellan, I., Burkill, P. H., Edwards, E. S., Harbour, D. S., Kennedy, H., Llewellyn, 
C., Mantoura, R. F. C., Morales, C. E., Pomroy, A. J., and Turley, C. M.: The physical and chemical environment and changes in community structure associated with bloom evolution: the Joint Global Flux Study North Atlantic Bloom Experiment, Deep-Sea Res., 40, 347-368, 1993.

Xie, W. H., Shiu, W. Y., and Mackay, D.: A review of the effect of salts on the solubility of organic compounds in sea water, Mar. Environ. Res., 44, 429-444,1997.
Yentsch, C. M. and Reichert, W. L.: The interrelationship between water-soluble yellow substances and chloroplastic pigments in marine algae, Botanica Mar., 65-74, 1961. 